\title{
Utilisation of Waste-Based Geopolymer in Asphalt Pavement Modification and Construction-A Review
}

\author{
Abdalrhman Milad 1,*(D), Ahmed Suliman B. Ali ${ }^{2}$, Ali Mohammed Babalghaith ${ }^{3} \mathbb{D}$, Zubair Ahmed Memon $4, * \mathbb{D}$, \\ Nuha S. Mashaan ${ }^{5}$, Salaheddin Arafa ${ }^{2}$ and Nur Izzi Md. Yusoff ${ }^{1}(\mathbb{D}$
}

1 Department of Civil Engineering, Universiti Kebangsaan Malaysia, UKM Bangi 43600, Selangor, Malaysia; izzi@ukm.edu.my

2 Faculty of Civil Engineering and Built Environment, University Tun Hussein Onn Malaysia,

Parit Raja 86400, Johor, Malaysia; algowel@yahoo.com (A.S.B.A.); arafa.uthm@gmail.com (S.A.)

3 Centre for Transportation Research, Department of Civil Engineering, Faculty of Engineering, University of Malaya, Kuala Lumpur 50603, Malaysia; bablgeath@hotmail.com

4 Department of Engineering Management, College of Engineering, Prince Sultan University (PSU), Riyadh 11586, Saudi Arabia

5 School of Civil \& Mechanical Engineering, Curtin University, Bentley, WA 6102, Australia; nuhas.mashaan1@curtin.edu.au

* Correspondence: miladabdalrhman@siswa.ukm.edu.my (A.M.); zamemon@psu.edu.sa (Z.A.M.)

Citation: Milad, A.; Ali, A.S.B.; Babalghaith, A.M.; Memon, Z.A.; Mashaan, N.S.; Arafa, S.; Md. Yusoff, N.I. Utilisation of Waste-Based Geopolymer in Asphalt Pavement Modification and Construction-A Review. Sustainability 2021, 13, 3330. https://doi.org/10.3390/su13063330

Academic Editor: Hussain Bahia

Received: 14 February 2021

Accepted: 11 March 2021

Published: 17 March 2021

Publisher's Note: MDPI stays neutral with regard to jurisdictional claims in published maps and institutional affiliations.

Copyright: (c) 2021 by the authors. Licensee MDPI, Basel, Switzerland. This article is an open access article distributed under the terms and conditions of the Creative Commons Attribution (CC BY) license (https:// creativecommons.org/licenses/by/ $4.0 /)$.

\begin{abstract}
The use of geopolymer in pavement constructions is strongly encouraged. Many studies have demonstrated the vast potential of using industrial-by-products-based geopolymers. This paper discusses the modification of asphalt binders with geopolymers, namely geopolymer-modified asphalt (GMA) and geopolymer-modified asphalt mixture (GMAM). In addition, curing geopolymer materials, engineering properties, production techniques, and prospective utilisation in the pavement construction, such as durability and sustainability, are also discussed. The literature review showed that many industrial by-products, including red mud, blast furnace slag, fly ash, and mine waste, are used to produce geopolymers because of the metal components such as silicon and aluminium in these materials. The geopolymers from these materials influence the rheological and physical properties of asphalt binders. Geopolymers can enhance asphalt mixture performance, such as stability, fatigue, rutting, and low-temperature cracking. The use of geopolymers in asphalt pavement has beneficial impacts on sustainability and economic and environmental benefits.
\end{abstract}

Keywords: geopolymers; eco-friendly; asphalt pavement industry; hot-mix asphalt; warm-mix asphalt; reclaimed asphalt pavement; industrial wastes

\section{Introduction}

Geopolymers are amorphous inorganic materials prepared by the activation of aluminosilicate precursors with hydroxides, carbonates, or silicates of alkali or alkaline earth metals [1]. These materials are considered greener materials because of their lower carbon emissions. In their effort to reduce the harmful effects of wastes, researchers are exploring using industrial by-products, such as red mud, fly ash (FA), blast furnace slag, and mine waste, to produce geopolymers [2-4]. Researchers are showing more interest in geopolymers because they are viable, inexpensive, and environmentally-friendly additives that can replace organic materials polymers in road construction. One benefit is a considerable reduction in the utilisation of new construction materials and the minimisation of the disposal of construction materials in landfills. The use of geopolymers leads to a green, sustainable, and eco-friendly construction that reduces the need to harvest natural resources [5]. Moreover, recycling green material waste is of great significance to civil engineers for sustainable development, which renders geopolymer a prospective future in civil engineering applications such as pervious concrete, geotechnical soil engineering, pavement engineering, and civil engineering works. 
The interest in geopolymer research publication started in 1979 with an increasing number of articles on geopolymers. Figure 1 shows that the investigations on geopolymer began to intensify in the early 2000s. However, due to the growing attention to modify asphalt binder with geopolymer, it is found that the materials are able to enhance the durability and sustainability of asphalt material production and subsequently improves the economic and environmental aspects [6].

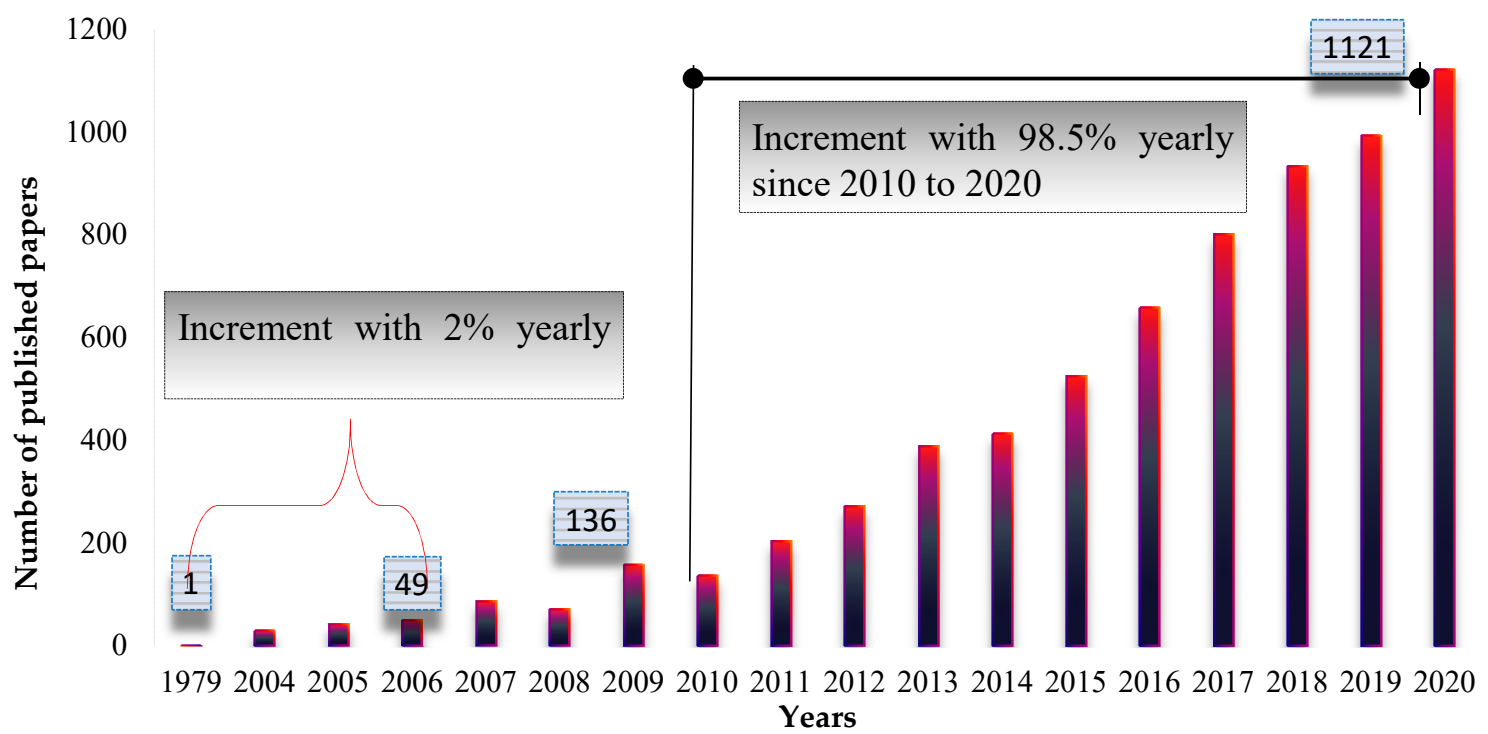

Figure 1. Annual increases in geopolymer research and publication.

There is a linear trend for the published articles on geopolymer technology between 2010 and 2020, with an increment of 98.5\%. In the past year, almost 1000 articles were published in peer-review journals, which indicate the active global exploration of the use of geopolymers. This study analysed the ten-year publication trend by considering the geographical distribution of the papers published between 2010 and 2020.

Asphalt binder modification has been practised for over 50 years. The recent interest in modified asphalt binders is due to their superior chemical properties, high-temperature stability, adhesion behaviour, extended durability, and excellent mechanical strength [2]. Geopolymer-modified asphalt (GPMA) is a combination of additive or modifier used as a construction material in asphalt mixtures $[7,8]$. There is not much research on geopolymers during the past four decades, and the interest in geopolymers is a recent phenomenon [8].

A geopolymer material is a new replacement of conventional asphalt binders with higher strength; in the geopolymer industry, wastes have strengthened as raw materials for geopolymer preparation, such as coal gangue, FA, tailings, and slag [6]. However, the innovative use of geopolymer in warm mix asphalt (WMA) additives is expected to pave the way for using industrial wastes and reduce the asphalt-mixing temperature. Both materials are important in utilising substantial waste resources and enhancing environmental protection [6-9]. Moreover, the benefits of GMAM are lower carbon dioxide production emissions, more significant chemical and thermal resistance, and better mechanical properties at both ambient and extreme conditions.

Furthermore, the cost of producing modified asphalt is 15\% to $50 \%$ lower than for conventional asphalt [9]. The cost of recycling and using geopolymers as road construction materials are relatively low [10]. Recent studies have devoted efforts to produce cleaner asphalt binder mixtures by reducing production, mixing, and compaction, temperature composites as a filler of hot-mix asphalt (HMA) that effective bitumen volatile organic compounds (VOCs) could be reduced using geopolymer additives $6 \%$ total weight of asphalt binder [11]. 
Several researchers have reported that the performance of geopolymer stabilised reclaimed asphalt pavement (RAP) satisfied the requirements of pavement base and subbase applications. RAP is increasingly becoming a popular material in unbound base and subbase applications due to its lower cost than natural quality aggregates. The sustainable usage of RAP also leads to significant economic savings for constructing new highway pavements [12-15]. Therefore, this study aims to provide a comprehensive review of the components, clean production techniques, heat curing methods, and properties of GMAM to provide insights into the potential application of GMAM material in different mixtures to produce WMA, RAP, and HMA.

Figure 2 shows the geographical distribution of the papers published in the previous ten years. Chinese researchers published $13 \%$ of the articles, followed by Indian ( $8 \%$, Australian (10\%), and American (7\%) researchers. Almost half of the papers were published in Asia (47\%), especially China, India, Malaysia, and Saudi Arabia, 26\% were published in Europe, and 27\% were published in Africa, America, and Oceania.

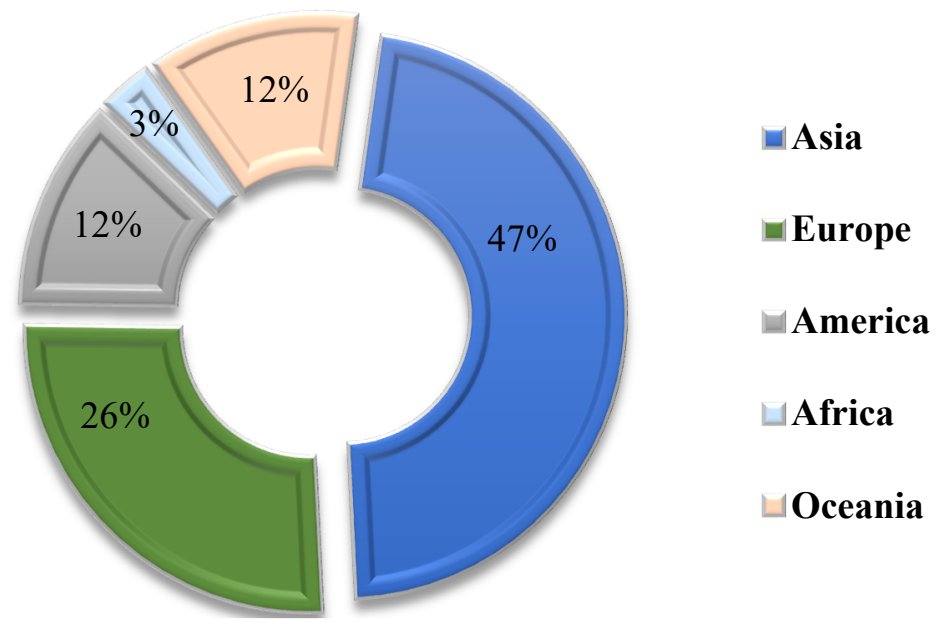

Figure 2. Geographical distribution of the published articles.

This paper presents a comprehensive review of waste-based geopolymer, including its current status, curing regimes, production method, properties, and potential uses in the pavement construction industry.

\section{Geopolymer}

Several researchers have explored the feasibility of using industrial by-products such as blast furnace slag and FA as precursor materials [2]. The precursor materials are inorganic polymers derived through dissolution, polycondensation, and aluminosilicate precipitation at ambient temperature. One of the benefits of geopolymers is their high compressive and flexural strengths. The manufacture of geopolymers is carried out at an ambient temperature, emits less carbon dioxide, and uses inexpensive waste materials (FA, silica fume, various types of clays, and agricultural wastes) [16]. The consistency of FA properties is non-guaranteed because of the presence of contaminants such as iron and calcium. Therefore, geopolymers are the critical resources for the future production of geopolymer asphalt $[16,17]$. Other precursor sources are raw material geopolymers and rocks with high aluminium oxide contents [18]. The performance-based research focused on FA-modified asphalt nature, while others focused on the kaolin geopolymer binders performance [7].

The production of geopolymer requires a chemical activator that serves as a mild alkaline reagent. It has the properties of an aqueous silicate solution that contains metal alkali and silica, with a molar ratio $\mathrm{SiO}_{2}: \mathrm{M}_{2} \mathrm{O}$ exceeding 1.65 , where $\mathrm{M}$ is an alkali metal, either potassium (K) or sodium (Na) [19]. Figure 3 shows that any material with a high silicon and aluminium content is suitable as raw materials, which means that many materials can 
produce geopolymers. Kaolinite is the initial material used to obtain geopolymers. Table 1 shows the chemical composition of geopolymers.

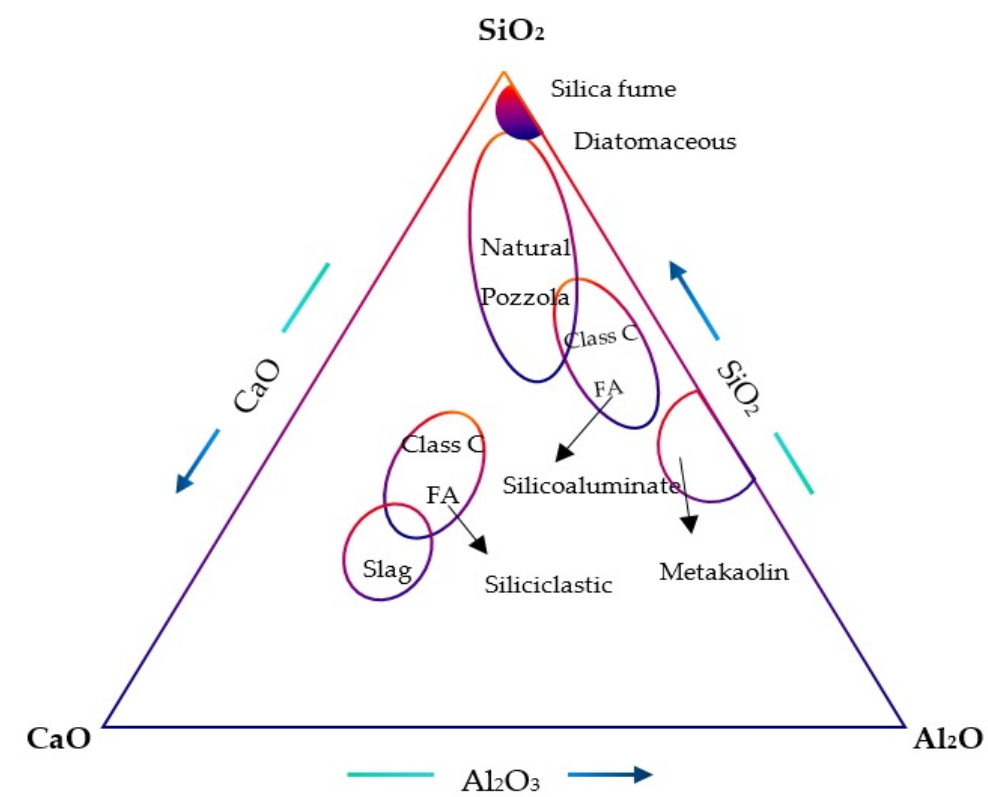

Figure 3. The ternary chemical composition of materials $\left(\mathrm{SiO}_{2}-\mathrm{CaO}-\mathrm{Al}_{2} \mathrm{O}_{3}\right)$.

Table 1. Chemical composition of the different types of geopolymer (\%).

\begin{tabular}{cccccc}
\hline Oxide & $\begin{array}{c}\text { Fly ash } \\
\text { (FA) [16] }\end{array}$ & $\begin{array}{c}\text { Kaolin } \\
\text { [5] }\end{array}$ & $\begin{array}{c}\text { Metakaolin } \\
\text { (MK) [17] }\end{array}$ & $\begin{array}{c}\text { Silica Fume } \\
\text { [18] }\end{array}$ & $\begin{array}{c}\text { Alkaline Silicate } \\
\text { Solution [19] }\end{array}$ \\
\hline $\mathrm{SiO}_{2}$ & 57.2 & 52.00 & 55.90 & 94.92 & 24.9 \\
$\mathrm{Al}_{2} \mathrm{O}_{3}$ & 23.5 & 35.00 & 37.20 & 0.02 & - \\
$\mathrm{F}_{2} \mathrm{O}_{3}$ & 3.8 & 1.00 & 1.70 & 1.28 & - \\
$\mathrm{TiO}_{2}$ & - & 0.90 & 2.40 & - & - \\
$\mathrm{CaO}$ & 9.3 & $<0.05$ & 0.11 & 0.03 & - \\
$\mathrm{MgO}$ & 1.0 & 0.70 & 0.24 & 0.01 & - \\
$\mathrm{K} \mathrm{K}_{2} \mathrm{O}$ & - & 2.00 & 0.18 & 0.15 & - \\
$\mathrm{Na}_{2} \mathrm{O}$ & 2.43 & 0.05 & 0.27 & 0.28 & 18.5 \\
$\mathrm{SO}_{3}$ & 0.2 & - & 0.02 & 0.02 & - \\
$\mathrm{P}_{2} \mathrm{O}_{5}$ & - & 0.1 & 0.17 & - & - \\
Loss in ignition & - & - & 0.80 & - & - \\
\hline
\end{tabular}

\subsection{Materials}

The geopolymer used in asphalt binder modification is derived from various waste products. The following subsections give a detailed description of the waste materials.

\subsubsection{Fly Ash (FA)}

FA contains considerable amounts of silicon dioxide $\left(\mathrm{SiO}_{2}\right)$ (both crystalline and amorphous), aluminium oxide $\left(\mathrm{Al}_{2} \mathrm{O}_{3}\right)$, and calcium oxide $(\mathrm{CaO})$ and is the main mineral compound in coal-bearing rock strata. Preparation of FA geopolymer often involved using aluminosilicate and potassium hydroxide. Figure 4 is the scanning electron microscopy (SEM) image from the LEO Stereo-scan 440, which shows that FA's morphology consists of hollow spherical particles [20]. 


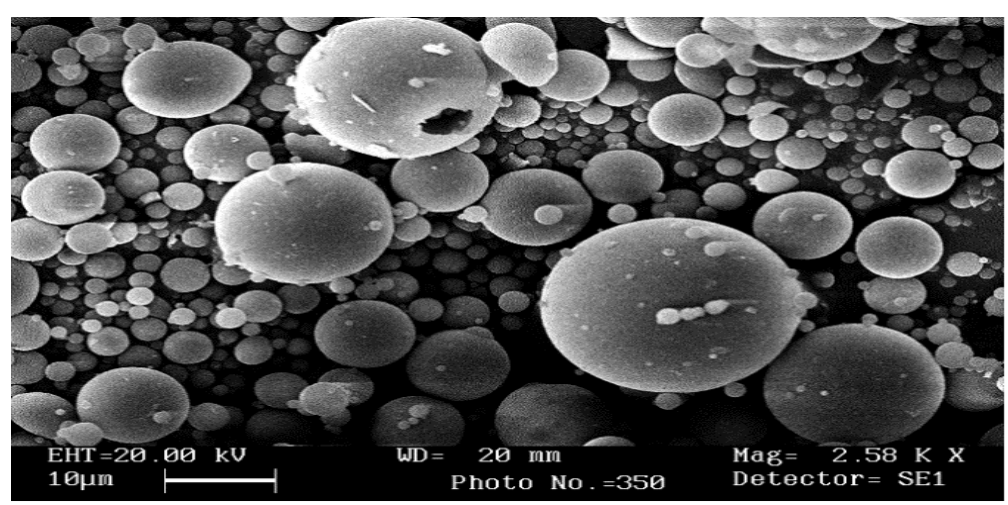

Figure 4. Scanning electron microscopy (SEM) image of FA [21].

\subsubsection{Commercial Fly Ash}

The commercial FA from a coal-fired power plant comprises a heterogeneous mixture of silica glasses, aluminosilicate, and a minute amount of crystalline materials that include mullite, hematite, magnetite, and quartz [22]. The inert particles are the end-products of the initial coal combustion [23]. Table 2 shows the chemical composition of class $C$ and class $F$ fly ash. Figure 5 shows that class $C$ and class F FA's morphology is primarily amorphous aluminosilicate glass between $10 \mu \mathrm{m}$. Furthermore, the shape and morphology of SEM images at $10 \mu \mathrm{m}$ was observed for class C FA as shown in Figure $5 a$,b. Hence, for class $C$ FA, the existence of asymmetrical clusters of $>10 \mu \mathrm{m}$, the chemical composition of which corresponded to anhydride compared to class F of FA, while in the case of the FA-C, their contribution is the much lower bulk as shown in Figure 5b.

Table 2. The chemical composition of class F and class C fly ash [25].

\begin{tabular}{cccccccccc}
\hline $\begin{array}{c}\text { Materials } \\
\text { Mass \% }\end{array}$ & $\mathrm{SiO}_{\mathbf{2}}$ & $\mathrm{Fe}_{2} \mathbf{O}_{\mathbf{3}}$ & $\mathbf{A l}_{\mathbf{2}} \mathbf{O}_{\mathbf{3}}$ & $\mathbf{C a O}$ & $\mathbf{K}_{\mathbf{2}} \mathbf{O}$ & $\mathbf{N n}_{\mathbf{2}} \mathbf{O}_{\mathbf{3}}$ & $\mathbf{S O}_{\mathbf{3}}$ & $\mathbf{M g O}$ & $\mathbf{L O I}$ \\
\hline Fly ash class C & 20.7 & 32.0 & 9.01 & 2.09 & 1.04 & 0.07 & 00.69 & 1.61 & 2.97 \\
Fly ash class F & 55.23 & 10.17 & 25.95 & 12.65 & 0.65 & 0.55 & 0.86 & 0.18 & 5.25 \\
\hline
\end{tabular}

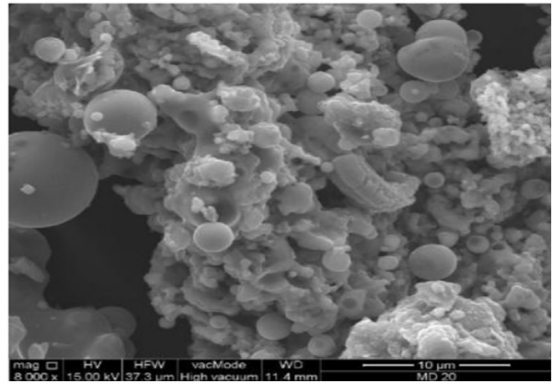

(a)

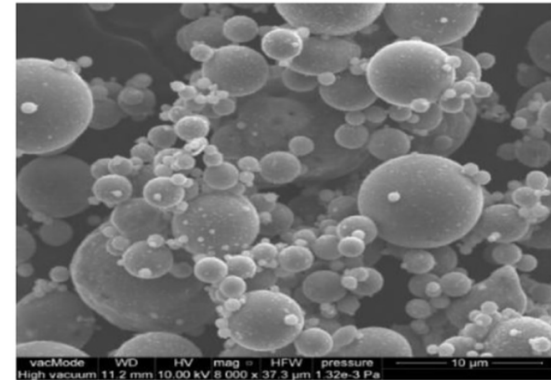

(b)

Figure 5. SEM Image of Raw Commercial class F (a) and C (b) fly ash [24].

The final reaction product of alkali-activated FA is an amorphous to semi-crystalline structure similar to a zeolite precursor. The activation degree reaction of geopolymer paste is dependent on the ash materials glassy content [22].

\subsubsection{Metakaolin}

Metakaolin (MK), including kaolinite, is a source of aluminosilicate material. MK is manufactured through dihydroxylation calcification of kaolin clay at between 500 and $900{ }^{\circ} \mathrm{C}$. This process chemically bonds the water and transforms a large portion of the octahedrally coordinated aluminium in the kaolin into five- and four-fold configurations [26]. 
MK has a small particle size, making it suitable for gloss materials [27]. Platy kaolinite particles provide an excellent coating opacity and printability. MK with a solid/liquid (S/L) ratio of 0.8 has the highest microstructure strength and a dense geopolymer matrix [28]. The presence of these minerals in MK influences the reaction steps and final properties of GPMA. It could also affect geopolymer modification due to the distinct forms and mineral composition of the MK.

\subsubsection{Sodium Hydroxide $(\mathrm{NaOH})$}

$\mathrm{NaOH}$ is an alkaline activator in the production of geopolymers. While it lacks activation level maintenance as the $\mathrm{K}^{+}$ion, sodium cations are comparatively smaller than potassium cations. It can migrate throughout the paste network with relative ease and increase sensitisation. $\mathrm{NaOH}$ has a high charge density that promotes additional zeolite formation energy. The properties of the resulting paste are dependent on the concentration and molarity of the activating solution. Chemical dissolution is accelerated by a high ratio of $\mathrm{NaOH}$, which reduces the generation of carbon-hydrogen $(\mathrm{CH})$ during binder formation [22].

\subsection{Chemical Properties}

The geopolymer comprises two components, a chemical activator and an aluminosilicate material. There are two significant properties of aluminosilicate materials, raw, rock-based materials and industrial by-products [29]. The formation of geopolymer originators is dependent on the dissolution of alumina and silicate from the initial Si-Al materials in the alkali silicate solution, where the degree of dissolution is dependent on alkali silicate concentration, the alkali silicate concentration, and the particle size of Si-Al. The catalysis of the polycondensation reaction is dependent on the alkali hydroxide. It allows the dissolution with the initial material reaction.

The geopolymer contains mainly $\mathrm{SiO}_{2}, \mathrm{Al}_{2} \mathrm{O}_{3}, \mathrm{Fe}_{2} \mathrm{O}_{3}$, and $\mathrm{MgO}$. FA, slag, $\mathrm{MK}$, and silica fume are in different classes depending on the total chemical composition. MK paste activation properties with alkali solution at $\mathrm{S} / \mathrm{L}$ ratios range between 0.40 and 1.20 [30]. The alkali activation solution for $\mathrm{MK}$ is $\mathrm{Na}_{2} \mathrm{SiO}_{3} / \mathrm{NaOH}$. In this case, distinct ratios displayed behaviour that the $\mathrm{S} / \mathrm{L}$ of 0.80 produced the highest value at the $\mathrm{Na}_{2} \mathrm{SiO}_{3} / \mathrm{NaOH}$ ratio of 0.20 . The mineral content of the $\mathrm{MK}$ influences the reaction process and final properties of GPMA.

\subsection{Morphological Properties}

The geopolymer morphology analysis can give quite valuable information regarding the surface topography and composition of the sample such as $\mathrm{Na}_{2} \mathrm{SiO}_{3}$, silica fume, and $\mathrm{NaOH}$ concerning the size, shape, and structure of geopolymers and the relationships of their constituent parts. In contrast, three-dimensional and topographical imaging can also be obtained [10]. However, the morphological evolution of calcium-rich ESP and alumino-siliceous precursor FA based geopolymer used SEM to analysis the structure of the FA geopolymer synthesised; the geopolymer products contain various topographies: dense and bulky geopolymer binders, FA balls, pores, micro-cracks, voids, and particles listed from lower than $1 \mu \mathrm{m}$ to more than $200 \mu \mathrm{m}$. FA particles are solid spheres that range from 1 to $100 \mu \mathrm{m}$ [21]. A difference in the chemical composition of class $C$ and class $F$ fly ash is the calcium content, where Class $C$ fly ash has a higher calcium content. Class $C$ fly has between 50 and $70 \%$ of pozzolanic compounds (alumina oxide, iron oxide, and silica oxide), while Class $\mathrm{F}$ fly ash has at least $70 \%$. In contrast, geopolymer mortar's flowability is reduced using GMA's high content due to the increase of non-spherical particles in the microstructure in the asphalt binder [24]. The spherical particles have the same fineness and micro size, and about $12.5 \%$ of the ash is retained in a $45 \mu \mathrm{m}$ mesh sieve [31].

Based on the micrograph illustrated in Figure 6, FA-based geopolymer's microstructure is a porous, heterogeneous mixture of non or partly-reacted FA grains, residual alkaline precipitates, and geopolymer gel. Besides, it shows the microstructure of the FA-based 
geopolymer at 12,000 magnifications [32]. Most of the particles are spherical, but some of the particles are fused. The macroparticles are called pedosphere. According to Oderji et al., the elemental data shows that more than $50 \%$ of the FA samples are amorphous alumino-silicate spheres and a smaller percentage of iron-rich spheres [30].

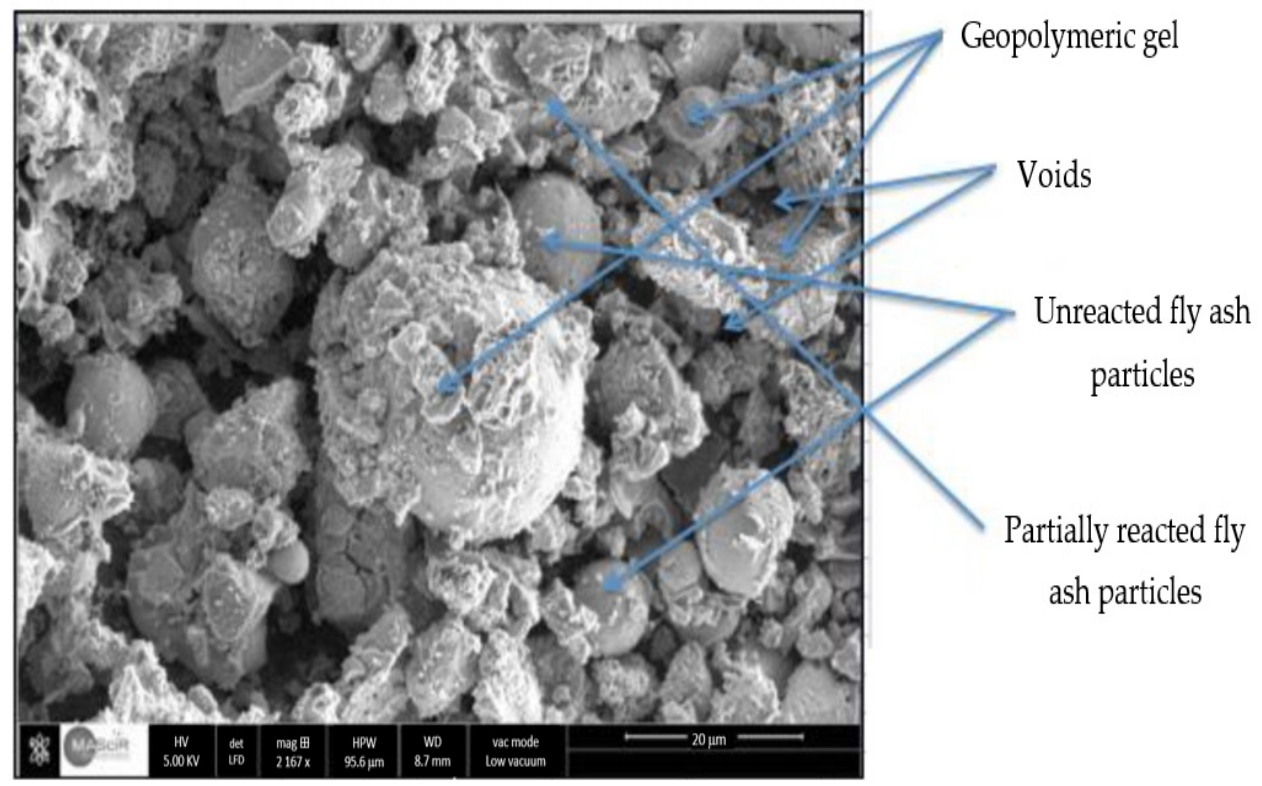

Figure 6. SEM micrographs for the FA geopolymer [32].

Most MK spots range from 1 to $20 \mu \mathrm{m}$. MK is a porous, angular-shaped, platy particle with a specific gravity of between 2.20 and 2.60. There is no one particular mixture that is the best for the geopolymers derived from an extensive range of sources. Essentially, MK comprises alternating buckled aluminate and silicate layers. The silicon is in a fourcoordination and aluminium mixture of 6-, 4-, and 5-coordination. There are discussions on the exact function of each of the three distinct coordination states of AI in terms of geopolymer behaviour. Generally, the strain in the bonding network formed during thermal dihydroxylation influences MK reactivity [27].

The relative silica content is critical in terms of chemistry [33]. Slag alters the pore size distribution of geopolymers and gives it a rough surface texture with crystalline, platy structures. The SEM micrographs show the porous structure [34,35].

\section{Characterisation of GMA}

A binder is a viscous liquid that flows smoothly at high temperatures. It has the behaviour of an elastic solid at relatively low temperatures. However, some of the input energy may spread within the asphalt and cause permanent degradation (viscous behaviour) [35]. Researchers categorised asphalt binder modifiers into several key groups based on their composition, fillers, hydrocarbons, agents, polymers (elastomeric and elastomeric), fibres, and anti-stripping property. These additives have critical chemical and physical properties that influence the performance of asphalt mixture pavement. Asphalt additives reduced mixture stiffness at low temperatures and increased the stiffness at high temperatures [36-40]. Table 3 summarises the elasticity of the mixtures under ambient temperature. 
Table 3. Types of asphalt, ratio, and activator geopolymers used in asphalt modification.

\begin{tabular}{|c|c|c|c|c|c|c|c|}
\hline Author & Year & Country & Objective & Geopolymer and Ratio & Asphalt Type & Activator & Key Findings \\
\hline Rosyidi et al. [2] & 2020 & Malaysia & $\begin{array}{l}\text { Investigate the strength, } \\
\text { chemical, morphology, } \\
\text { and adhesion properties } \\
\text { of geopolymers }\end{array}$ & $\begin{array}{l}\text { FA class F } \\
0,3,5,7,9 \%\end{array}$ & $80 / 100$ & $\begin{array}{l}\text { Sodium silicate } \\
\text { and } \mathrm{NaOH}\end{array}$ & $\begin{array}{l}\text { The optimal concentration for asphalt } \\
\text { binder modification is } 5 \% \text { geopolymer. }\end{array}$ \\
\hline Tang et al. [39] & 2020 & China, Hong Kong & Emission reduction & $\begin{array}{c}\text { MK } \\
\text { slag } \\
\text { silica fume } \\
0,6 \% \\
\end{array}$ & AH-90 \& PG64-28 & $\mathrm{NaOH}$ & Reduce volatile organic compounds. \\
\hline Hamid et al. [18] & 2020 & $\begin{array}{l}\text { Canada and the } \\
\text { USA }\end{array}$ & $\begin{array}{l}\text { Distresses caused by } \\
\text { flexible pavements }\end{array}$ & $\begin{array}{c}\text { FA-Based Geopolymer } \\
0,3,6 \text {, and } 9 \%\end{array}$ & PG58-28 & $\begin{array}{l}\mathrm{Na}_{2} \mathrm{SiO}_{3} \\
(8 \mathrm{M})\end{array}$ & $\begin{array}{l}\text { Increased temperature susceptibility, } \\
\text { shear modulus, rutting resistance, } \\
\text { high-temperature grading reduction in } \\
\mathrm{CO}_{2} \text {, and increase the percentage of } \\
\text { geopolymer not affecting the } \\
\text { microstructure of the binder. }\end{array}$ \\
\hline $\begin{array}{c}\text { Huynh, Magee, } \\
\text { and Woodward } \\
\text { [14] }\end{array}$ & 2020 & United Kingdom & $\begin{array}{l}\text { Investigate the traits of } \\
\text { semi-flexible composite } \\
\text { materials integrated with } \\
\text { geopolymer grouts } \\
\text { and RAP }\end{array}$ & $\begin{array}{c}\text { Ground-granulated } \\
\text { blast furnace slag } \\
\text { 40,50,60, 80\% } \\
\text { FA 20, 40, 50\% MK 20\% } \\
\text { silica fume } 20 \%\end{array}$ & RAP & $\begin{array}{c}\text { Geosil, with } 45 \% \\
\mathrm{Na}_{2} \mathrm{SiO}_{3}(1.6 \mathrm{M}) \\
0.27,0.33,0.38,0.52\end{array}$ & $\begin{array}{l}\text { Both geopolymer grout and RAP content } \\
\text { influenced performance. Improved } \\
\text { performance is associated with mixtures } \\
\text { of high-strength grout and low } \\
\text { RAP content. }\end{array}$ \\
\hline $\begin{array}{l}\text { Hamid, Baaj, and } \\
\text { El-Hakim [18] }\end{array}$ & 2019 & $\begin{array}{l}\text { Canada and } \\
\text { the USA }\end{array}$ & $\begin{array}{c}\text { Investigate the } \\
\text { possibility of using } \\
\text { by-product materials }\end{array}$ & $\begin{array}{l}\text { FA and glass powder } \\
\quad 0,4,8 \text {, and } 12 \%\end{array}$ & PG58-28 & $\begin{array}{l}100 \% \mathrm{NaOH}(8 \mathrm{M}) \\
\text { and } 50 \% \mathrm{Na}_{2} \mathrm{SiO}_{3}\end{array}$ & $\begin{array}{l}\text { Improved fatigue resistance, } \\
\text { rutting resistance. }\end{array}$ \\
\hline Khan et al. [20] & 2019 & Malaysia, Kuwait & $\begin{array}{l}\text { Determine the optimal } \\
\text { dose combination of } \\
\text { superplasticiser to fulfil } \\
\text { the flowability } \\
\text { requirement of grouts and } \\
\text { optimise the } \\
\text { compressive strength } \\
\end{array}$ & $\begin{array}{l}\text { Grouts, FA, and } 1.25 \% \\
\text { recycled waste } \\
\text { plastic (PET) }\end{array}$ & $\begin{array}{c}60 / 70 \\
\& \\
\text { PA } 20-35 \%\end{array}$ & $\begin{array}{c}\mathrm{Na}_{2} \mathrm{SiO}_{3}: \mathrm{NaOH}(3: 1) \\
\text { Superplasticizer 1\% } \\
\text { by FA }\end{array}$ & $\begin{array}{l}\text { Eco-friendly and contribute to } \\
\text { sustainable pavement construction. }\end{array}$ \\
\hline $\begin{array}{l}\text { Ariyadasa and } \\
\text { Nataatmadja [22] }\end{array}$ & 2019 & Australia & $\begin{array}{l}\text { Use geopolymer } \\
\text { as a modifier }\end{array}$ & $\begin{array}{c}\text { FA class FA and sodium } \\
\text { silicate } 2.5 \% \text { to } 6 \% \text { step } \\
0.5 \% \text { by mass of RAP }\end{array}$ & Type C170 & $\begin{array}{l}\mathrm{Na}_{2} \mathrm{SiO}_{3} \\
10 \mathrm{M}\end{array}$ & $\begin{array}{l}\text { Further study on geopolymer as a } \\
\text { supplementary binder in FB stabilisation } \\
\text { with } \mathrm{NaOH} \text { as an additional accelerator } \\
\text { is required. }\end{array}$ \\
\hline Tang et al. [7] & 2018 & China & $\begin{array}{l}\text { Comprehensive study } \\
\text { of WMA }\end{array}$ & $\begin{array}{c}\text { MK } \\
\text { Slag } \\
\text { silica fume } \\
0 \%, 2 \%, 6 \%, 10 \%\end{array}$ & $\begin{array}{l}\text { AH-90 } \\
\text { PG64-28 }\end{array}$ & $\begin{array}{l}\text { Silicon oxide, calcium } \\
\text { oxide, and } \\
\text { aluminium oxide }\end{array}$ & $\begin{array}{l}\text { The optimum dose of geopolymer } \\
\text { additive is } 6 \% \text { (by weight of the asphalt } \\
\text { binder) and the optimum mixing } \\
\text { temperature for WMA is around } 140{ }^{\circ} \mathrm{C} \text {. }\end{array}$ \\
\hline
\end{tabular}


Table 3. Cont

\begin{tabular}{|c|c|c|c|c|c|c|c|}
\hline Author & Year & Country & Objective & Geopolymer and Ratio & Asphalt Type & Activator & Key Findings \\
\hline Hoy et al. [15] & 2018 & Thailand & $\begin{array}{l}\text { Determine the impact of } \\
\text { geopolymerisation once } \\
\text { the slag is activated } \\
\text { by alkaline } \\
\text { activator-stabilised RAP }\end{array}$ & $\begin{array}{c}\mathrm{RAP}+20 \% \text { slag-based } \\
\text { geopolymer }\end{array}$ & RAP & $\begin{array}{c}\mathrm{NaOH}: \mathrm{Na}_{2} \mathrm{SiO}_{3} \\
40 \%: 60 \%, 50 \%: 50 \%\end{array}$ & $\begin{array}{c}\text { The suitable S-based } \\
\text { geopolymer-stabilised RAP can produce } \\
\text { RAP-S geopolymers as a sustainable } \\
\text { pavement base course and reduce } \\
\text { gas emission. }\end{array}$ \\
\hline $\begin{array}{c}\text { Dayal and } \\
\text { Soundarapandi } \\
\text { [13] }\end{array}$ & 2018 & India & $\begin{array}{l}\text { Evaluate the properties of } \\
\text { FA-based geopolymer } \\
\text { coated aggregates and } \\
\text { their effect on asphalt } \\
\text { mixtures characteristics }\end{array}$ & $\begin{array}{c}\text { (FA1, FA2) class F } 4,4.5, \\
5,5.5,6 \% \\
\text { FA-based geopolymer } \\
\text { coated aggregates }\end{array}$ & VG 10 & $\begin{array}{c}\text { FA1, at } \\
8 \mathrm{M}, 10 \mathrm{M}, 12 \mathrm{M}, 14 \mathrm{M}, \\
\text { and } 16 \mathrm{M} . \\
\text { FA2 at } 15 \mathrm{M}, 22 \mathrm{M}, \\
\text { and } 29 \mathrm{M} .\end{array}$ & $\begin{array}{l}\text { Geopolymers prepared with higher } \\
\text { calcium content increases strength. }\end{array}$ \\
\hline S.I.A Ali et al. [41] & 2017 & Turkey, Malaysia & $\begin{array}{l}\text { Investigate the use of fly } \\
\text { ash as a modifier. Perform } \\
\text { tests to evaluate } \\
\text { performance, including } \\
\text { softening point, viscosity, } \\
\text { and dynamic shear } \\
\text { rheometer (DSR) tests }\end{array}$ & $\underset{0,3,5,7 \%}{\mathrm{FA}}$ & $60 / 70$ & $\begin{array}{c}\mathrm{Na}_{2} \mathrm{SiO}_{3} \text { and } \mathrm{NaOH} \\
(8 \mathrm{M})\end{array}$ & $\begin{array}{l}\text { Improve resistance against rutting at } \\
\text { high temperatures. } \\
\text { The addition of } 5 \% \text { FA produced an } \\
\text { optimal result. }\end{array}$ \\
\hline Hoy et al. [15] & 2017 & $\begin{array}{l}\text { Thailand and } \\
\text { Australia }\end{array}$ & $\begin{array}{l}\text { Incorporate RAP and FA } \\
\text { in the pavement }\end{array}$ & $\begin{array}{l}\text { FA } \\
0,20 \%\end{array}$ & RAP-FA & $\begin{array}{c}\left(\mathrm{Na}_{2} \mathrm{SiO}_{3}\right),(\mathrm{NaOH}) \\
(10 \mathrm{M})\end{array}$ & $\begin{array}{l}\mathrm{NaOH} \text { has better durability performance } \\
\text { and formed stably cross-linked } \\
\text { energy saving and reduces greenhouse } \\
\text { gases emissions. }\end{array}$ \\
\hline S.I.A Ali et al. [42] & 2017 & Turkey & $\begin{array}{l}\text { Evaluate the performance } \\
\text { of using the } \\
\text { oscillation test }\end{array}$ & $\begin{array}{l}\text { FA class F } \\
0,3,5,7 \%\end{array}$ & $60 / 70$ & $\begin{array}{l}\mathrm{Na}_{2} \mathrm{SiO}_{3} \text { and } \mathrm{NaOH} \\
(8 \mathrm{M})\end{array}$ & $\begin{array}{c}\text { Enhanced viscoelastic properties of } \\
\text { asphalt binder. }\end{array}$ \\
\hline Ibrahim et al. [8] & 2016 & Malaysia & $\begin{array}{l}\text { Investigate the physical } \\
\text { properties and storage } \\
\text { stability of the asphalt } \\
\text { modified FA geopolymer }\end{array}$ & $\begin{array}{c}\text { FA } \\
0,1,2, \text { and } 3 \%\end{array}$ & $80 / 100$ & $\begin{array}{l}\mathrm{NaOH} \text { and } \mathrm{Na}_{2} \mathrm{SiO}_{3} \\
(8 \mathrm{M})\end{array}$ & $\begin{array}{l}\text { The addition of geopolymer into asphalt } \\
\text { binder improves permanent deformation } \\
\text { resistance compared to conventional } \\
\text { asphalt. }\end{array}$ \\
\hline Ibrahim et al. [43] & 2016 & Malaysia & $\begin{array}{c}\text { Investigate physical } \\
\text { properties and } \\
\text { storage stability }\end{array}$ & $\begin{array}{c}\text { FA class F } \\
0,3,5 \%, 7 \%, 9 \%\end{array}$ & $80 / 100$ & $\mathrm{Na}_{2} \mathrm{SiO}_{3}$ & $\begin{array}{c}\text { Addition of } 5 \% \text { FA produce } \\
\text { optimal results. }\end{array}$ \\
\hline Ismail [25] & 2011 & Malaysia & $\begin{array}{l}\text { Investigate the creep } \\
\text { properties of geopolymer } \\
\text { binder mixtures }\end{array}$ & FA, HMA & $80 / 100$ & $\underset{8 \mathrm{M}}{\mathrm{NaOH} \mathrm{Na}} \mathrm{SiO}_{3}$ & $\begin{array}{l}\text { Enhanced creep stiffness and } \\
\text { rutting resistance. }\end{array}$ \\
\hline
\end{tabular}

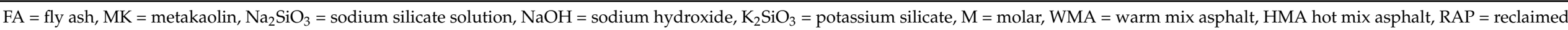

asphalt pavement. 


\subsection{Physical Characterisation}

The modified asphalt binder was evaluated to improve its physical properties, including visco-elastic properties and durability $[44,45]$. The evaluation considered temperature, mixing time, and characteristics of the asphalt and geopolymer to obtain balanced and superior modified asphalt because they influence the performance of asphalt mixes (Table 4).

Table 4. Physical properties of geopolymer-modified asphalt (GPMA).

\begin{tabular}{|c|c|c|c|c|c|c|}
\hline Reference & Year & Geopolymer \% & Ductility cm & $\begin{array}{c}\text { Viscosity at } \\
135{ }^{\circ} \mathrm{C} \mathrm{cP}\end{array}$ & $\begin{array}{c}\text { Penetration } \\
\text { of } 0.1 \mathrm{~mm}\end{array}$ & $\begin{array}{c}\text { Softening } \\
\text { Point }{ }^{\circ} \mathrm{C}\end{array}$ \\
\hline \multirow{5}{*}{ Rosyidi et al. [2] } & \multirow{5}{*}{2020} & $0 \%$ & 150 & 0.36 & 84 & 47 \\
\hline & & $3 \%$ & 126 & 0.42 & 76 & 49 \\
\hline & & $5 \%$ & 100 & 0.46 & 61 & 56.5 \\
\hline & & $7 \%$ & 91 & 0.43 & 68 & 53 \\
\hline & & $9 \%$ & 118 & 0.43 & 71 & 49.5 \\
\hline \multirow{4}{*}{ Tang et al. [7] } & \multirow{4}{*}{2018} & $0 \%$ & 137.4 & 0.6 & 85.1 & 48.5 \\
\hline & & $2 \%$ & 133.2 & 0.39 & 84.5 & 50.1 \\
\hline & & $6 \%$ & 130.1 & 0.3 & 83.4 & 50.3 \\
\hline & & $10 \%$ & 127.8 & 0.25 & 82.8 & 51.6 \\
\hline \multirow{5}{*}{ Ibrahim et al. [8] } & \multirow{5}{*}{2016} & $0 \%$ & 151 & 0.37 & 86 & 48.5 \\
\hline & & $3 \%$ & 127 & 0.43 & 78 & 50 \\
\hline & & $5 \%$ & 101 & 0.47 & 62 & 57.5 \\
\hline & & $7 \%$ & 92 & 0.44 & 69 & 54 \\
\hline & & $9 \%$ & 117 & 0.44 & 72 & 50 \\
\hline
\end{tabular}

The incorporation of up to $10 \%$ of weight content resulted in enhanced stability, density, flow, air voids, and asphalt mixture stiffness [2]. Future research should seek to improve high-temperature long-term storage stability without causing phase separation [17]. The GPMA mixture has a strong influence on performance due to the impact of elasticity properties. Modification of the asphalt mixture with a $10 \%$ modifier resulted in enhanced deformation $[46,47]$.

Asphalt binder modification with geopolymer improved stability, fatigue resistance, rutting resistance, and low-temperature cracking and reduced the flow of asphalt mixture [48]. It also reduced mixture viscosity and mixing temperature and enhanced workability.

\subsection{Chemical Characterisations}

\subsubsection{Fourier Transform Infrared Spectroscopy}

Geopolymers contain several metal components such as silicon, potassium, and aluminium, making them suitable for Fourier Transform Infrared Spectroscopy(FTIR) analysis $[49,50]$. The two major molecular components of asphalt are the polar and nonpolar groups. The polar compounds, such as asphaltene, are responsible for the elastic properties, while nonpolar groups, such as the maltene fractions, influence the mixture's viscous behaviour [2].

Because of the simplicity of analysis and minimal preparation required for FTIR, it is an ideal analytical tool for determining the presence of solvents in asphalt [7]. All spectra are obtained with 32 scans of a $4 \mathrm{~cm}$ resolution in wavelengths ranging from 600 to $4000 \mathrm{~cm}^{-1}$. According to Silva, asphaltenes are polar compounds with a high molecular weight [51]. FTIR spectroscopy can identify the functional and structural changes in the fraction of the binders caused by the severe oxidation process in the RTFO [52,53]. Table 5 shows the chemical composition of asphalt binders that comprises a complex mixture of mostly organic and organometallic compounds. 
Table 5. Elemental composition of an asphalt binder [54].

\begin{tabular}{ccccc}
\hline Element $(\mathbf{\%})$ & Mexican & Arkansas-Louisiana & Boscan & California \\
\hline Carbon $(\mathrm{C})$ & 83.77 & 85.78 & 82.90 & 86.77 \\
Hydrogen $(\mathrm{H})$ & 9.91 & 10.19 & 10.45 & 10.93 \\
Nitrogen $(\mathrm{N})$ & 0.28 & 0.26 & 0.78 & 1.10 \\
Sulphur $(\mathrm{S})$ & 5.5 & 3.41 & 5.43 & 0.99 \\
Oxygen $\left(\mathrm{O}_{2}\right)$ & 0.77 & 0.36 & 0.29 & 0.20 \\
Vanadium $(\mathrm{ppm})$ & 180 & 7 & 1380 & 4 \\
Nickel $(\mathrm{ppm})$ & 22 & 0.4 & 109 & 6 \\
\hline
\end{tabular}

Table 6 highlighted FTIR band's effect on material behaviours, which shows that the materials exhibit different behaviours. Maltenes comprise three groups: saturates, resins, and aromatics $[55,56]$. The saturated compounds consist primarily of branched-chain and straight aliphatic hydrocarbons, alkyl-naphthenes, and alkyl-aromatics. According to Alehyen and Zhang, the saturated compounds make up 5\% to 20\% of the GPMA binder. The resins, which are the strong adhesive of the binder, are made up of carbon and hydrogen with traces of oxygen [32,57].

Table 6. Wavenumber and band assignment for different materials in FTIR.

\begin{tabular}{|c|c|c|c|c|c|}
\hline $\begin{array}{l}\text { Wavenumber } \\
\quad\left(\mathrm{cm}^{-1}\right)\end{array}$ & FA & MK & Silica Fume & Geopolymer & Assignment \\
\hline 3441 & $\sqrt{ }$ & $\sqrt{ }$ & $\sqrt{ }$ & $\sqrt{ }$ & $\begin{array}{c}\mathrm{OH} \text { groups of } \mathrm{Si}-\mathrm{OH} \text { and water molecules that are } \\
\text { adsorbed on the FA surface }\end{array}$ \\
\hline 3432 & & & $\sqrt{ }$ & $\sqrt{ }$ & $\begin{array}{l}\mathrm{OH} \text { groups of } \mathrm{Si}-\mathrm{OH} \text { and water molecules that are } \\
\text { adsorbed on the FA geopolymer surface }\end{array}$ \\
\hline 1660 & & & & $\sqrt{ }$ & Stretching of $\mathrm{H}-\mathrm{O}-\mathrm{H}$ \\
\hline 1622 & $\sqrt{ }$ & & & & Stretching of $\mathrm{H}-\mathrm{O}-\mathrm{H}$ and $\mathrm{O}-\mathrm{H}$ \\
\hline 1451 & & & $\sqrt{ }$ & $\sqrt{ }$ & O-C-O stretching (carbonates) \\
\hline $\begin{array}{c}1075 \\
997\end{array}$ & $\sqrt{ }$ & $\sqrt{ }$ & $\sqrt{ }$ & . & Al-O-Si and Si-O-Si asymmetric stretching \\
\hline 894 & & & $\sqrt{ }$ & $\begin{array}{l}\sqrt{ } \\
\sqrt{ }\end{array}$ & Si-OH stretching \\
\hline 795 & $\sqrt{ }$ & & & & \\
\hline 771 & & & & $\sqrt{ }$ & \\
\hline 733 & & & & $\sqrt{ }$ & Al-U bending vibration \\
\hline 611 & & & & $\sqrt{ }$ & \\
\hline $558-560$ & $\sqrt{ }$ & $\sqrt{ }$ & & $\sqrt{ }$ & Al-O-Si and Si-O-Si asymmetric stretching \\
\hline $420-500$ & $\sqrt{ }$ & $\sqrt{ }$ & $\sqrt{ }$ & $\sqrt{ }$ & $\mathrm{Al}-\mathrm{O}$ and $\mathrm{Si}-\mathrm{O}-$ bending vibration \\
\hline
\end{tabular}

Geopolymers can serve as asphalt binder modifiers through the wet or dry process. Rosyidi et al. employed the FTIR spectra to analyse geopolymer-modified asphalt binder and discovered a slight change in the functional groups. The aromatic $\mathrm{C}-\mathrm{C}$ stretching peaks occurred at approximately $1600 \mathrm{~cm}^{-1}$ (stretch), $1475 \mathrm{~cm}^{-1}$. The maximum stretching of the C-N amine group occurred at $1390 \mathrm{~cm}^{-1}$ [2]. According to Hamid et al., the geopolymer spectra at 3432, 444, and $997 \mathrm{~cm}^{-1}$ are the most critical transmission bands [18].

Geopolymer FA is an influential group at $1075 \mathrm{~cm}^{-1}$ because of the Al-O-Si or Si-O-Si unequal stretching band on the description curve compared to the other geopolymers investigated in this research the Al-O-Si bond is at the $538 \mathrm{~cm}^{-1}$ bands [58-60].

The geopolymer did not significantly change the FTR spectrum, which means there is no change in the functional group due to the low geopolymer percentage. The geopolymer's absorption may overlap with the asphalt binder's absorption because of the high amount of asphalt binder used [61,62].

The addition of the small amount of geopolymer (less than 3\%) has a negligible effect on the modified binder's FTIR spectra [14]. However, the modifications added in temperature difference with higher than $4{ }^{\circ} \mathrm{C}$ is evidence of segregation in storage stability and is considered unstable. The long chains tend to align and flow as the load 
or temperature rises, which causes the asphalt to behave as a viscous liquid instead of an elastic solid. The molecules return to their initial shape (elastic behaviour) upon removal of stress or during cooling.

According to Rosyidi et al., geopolymers can release water [2]. These observations indicate that amorphous products were generated during the mixing process. Consequently, the sol converts into a colloidal gel structure [3], which resulted in better behaviour at higher temperatures in terms of permanent deformation [63].

\subsubsection{Scanning Electron Microscopy (SEM)}

SEM produces an image by scanning a focused electron beam across a specimen. Geopolymers are molecules comprising thousands or hundreds of atoms [17,64]. Geopolymers alter the microstructure of asphalt binders by making the network structures more coarse [15]. The denser fibril structure in the SEM image indicates a stiffer binder [13].

This study performed the SEM test to determine the microstructure of all modified asphalt binders. The results showed no significant difference in the fibril structure of the asphalt binders modified with 3,6, and 9\% geopolymer. Figure 7 shows that the nanoparticles are well-dispersed, and the microstructure is homogeneous without any clustering of the modifier [18]. Based on the investigation of the SEM images appears that the virgin asphalt binder $0 \%$ additive in Figure 7 a compared to $9 \%$ geopolymer additive not affecting the microstructure. Thus, $9 \%$ revealed a minor effect on the ranges for modified asphalt binder geopolymer as shown Figure $7 \mathrm{~b}$.

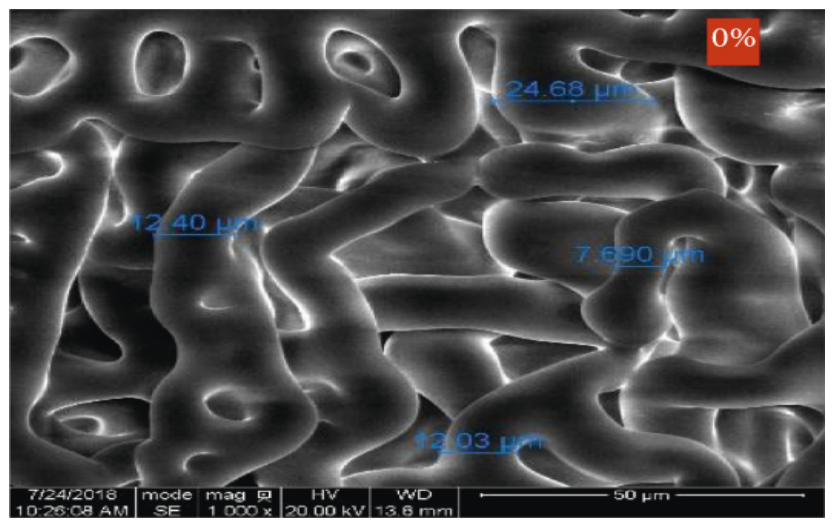

(a)

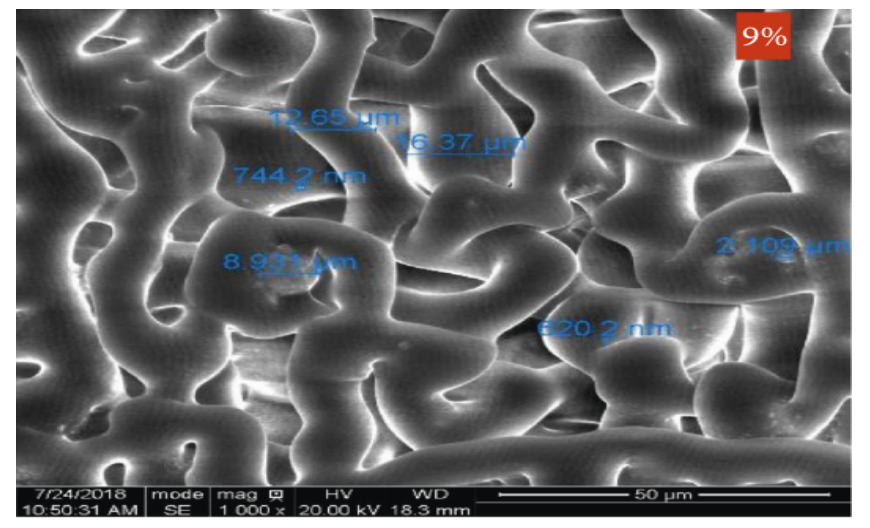

(b)

Figure 7. SEM micrographs of the geopolymer-modified asphalt; virgin asphalt binder $0 \%$ additive (a) and $9 \%$ geopolymer additive (b) [18].

Figure 8 shows that the geopolymer-modified binders have slightly smaller fibril diameters than the original binder. The geopolymerisation produced tiny zeolite crystals on the geopolymer surface. The crust of reaction products binds weakly to the microspheres. Such bonding between the grains is formed through chemical reactions [65]. The geopolymer particles are well-dispersed and have good compatibility with the asphalt binder. The incorporation of the geopolymer into the asphalt binder resulted in an improvement. The addition of varying percentages of geopolymer did not affect the binder's microstructure. Generally, the geopolymer enhanced the binding ability of the asphalt binders [66]. Figure 8 shows the SEM micrograph for silica fume geopolymer-modified asphalt. The particles are spherical and less than $1 \mu \mathrm{m}$ in diameter. 


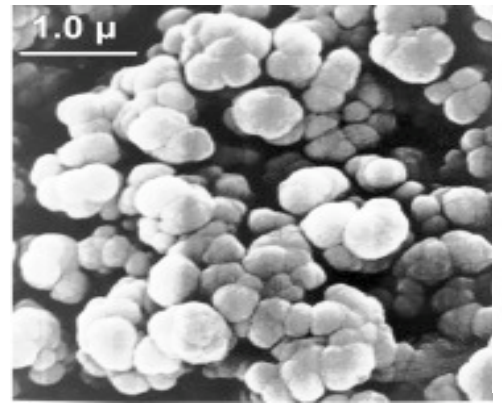

(a)

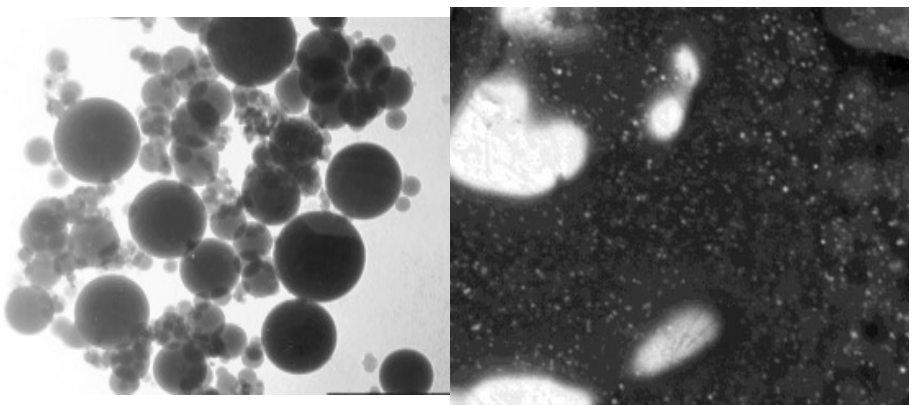

(b)

(c)

Figure 8. (a) Silica fume, (b) the transmission electron microscope dispersed individual particles, and (c) geopolymermodified asphalt [67].

The geopolymer-modified asphalt binders with similar physical properties could produce different SEM patterns that evolve in different ways. MK geopolymer-modified binders have significantly enhanced the structural chain characteristics and storage stability. The particle size of MK relative $(1.5 \mu \mathrm{m}$ vs. $0.1 \mu \mathrm{m})$ with different sizes is shown in Figure 9 [62]. The SEM image shows the morphological changes in the MK-modified geopolymer [2]. The optimum quantity for asphalt modification is five percent of the modifier.

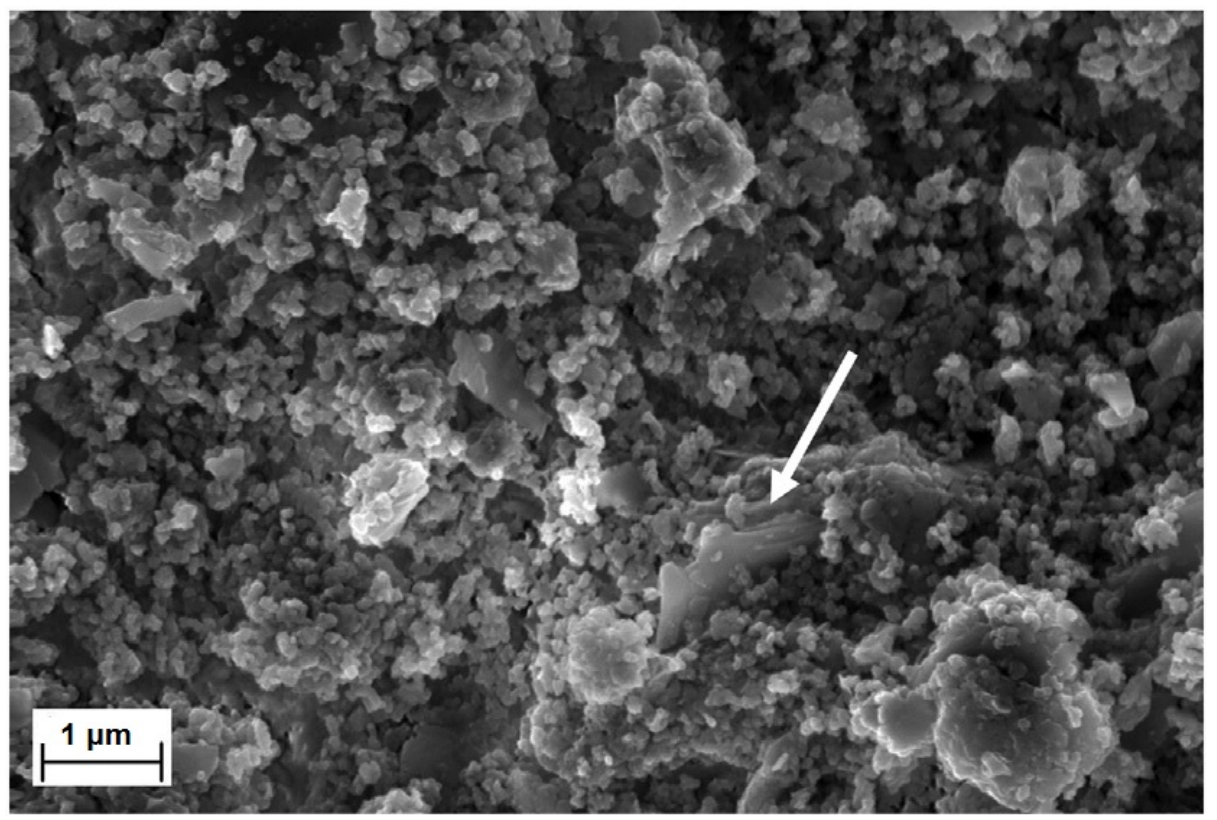

Figure 9. Micrograph of MK geopolymer [62].

The incorporation of higher geopolymer percentages could increase the asphaltene levels in the asphalt binder $[5,68,69]$. The enhanced binder could improve asphalt stiffness and damage resistance [70].

\subsubsection{Geopolymer Binder and Reaction Mechanisms}

According to Duxson, there are five steps in a geopolymer reaction. The first step is the dissolution of source material by highly alkaline ions to produce silicate and aluminate species [70]. The second step is blending the silicate and aluminate species to obtain an aluminosilicate solution. Third, the highly concentrated solution with a high $\mathrm{pH}$ initiates the gelation process that produces geopolymer gel. The fourth step is the reorganisation of the gel network, which forms the geopolymer microstructure and pores. The fifth 
step produces the three-dimensional geopolymer added to the asphalt binder to obtain GMA [71,72].

Several factors influence the GMA: activating solutions associated with silicate concentration $\left(\mathrm{SiO}_{2} / \mathrm{M}_{2} \mathrm{O}\right.$ ratio), the type of alkali metal cations, and the alkali solution $\left(\mathrm{H}_{2} \mathrm{O} / \mathrm{M}_{2} \mathrm{O}\right.$ ratio, where $\mathrm{M}$ is equal to $\mathrm{Na}$ and $\left.\mathrm{K}\right)$. The aluminosilicate sources dissolve into $\mathrm{SiO}_{4}$ and $\mathrm{AlO}_{4}$ tetrahedral units involved in the polycondensation process, as displayed in Figure 10 [73].

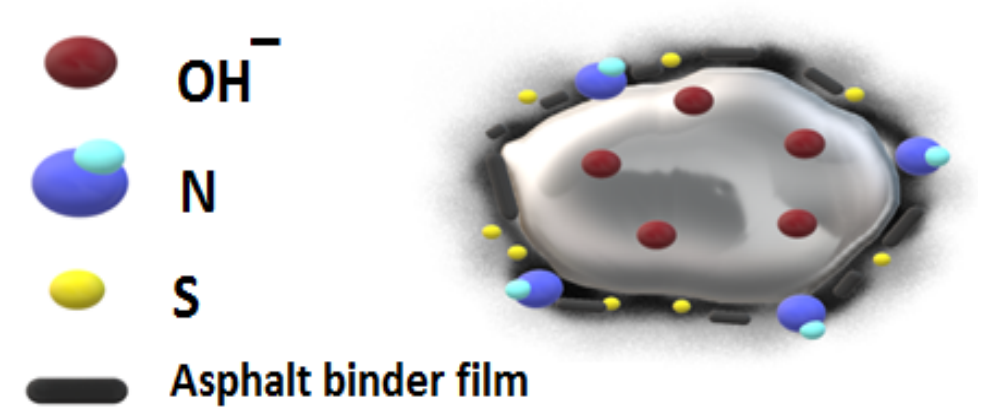

Figure 10. Interaction in the geopolymer modified asphalt.

Geopolymers can form in systems with low $\mathrm{Si} / \mathrm{Al}$ ratios, elevated curing temperatures, or where $\mathrm{Li}^{+}$is the alkali cation with or without the presence of amorphous [41]. The curing conditions' factors such as curing duration, humidity, and temperature affect geopolymer's strength $[10,74]$. However, the critical difference between GPMA and other asphalt modifiers is the geopolymer component. The aluminium and silicon oxides exist in FA, slag, silica fume, and MK in geopolymer, improving geopolymer-modified asphalt binder performance. Moreover, the geopolymer binds the loose coarse aggregates and other materials such as the filler. The properties and amount of the component materials determine the viscoelasticity and strength of GPMA. Storage stability is how easily the GPMA can be consolidated, transported, and placed without losing homogeneity or stability. It is dependent on the features of asphalt's modifiers affected by the consistency and the materials in the GPMA [60].

However, the casting of GPMA in actual construction requires particular attention to enhancing the asphalt pavement in terms of permanent damage, water surface tension, compatibility, homogeneity, and workability of both the asphalt binder and asphalt mixture. These parameters are affected by the binder's shape, modifier, aggregates, mixing, particle size, and distribution $[6,15,75]$.

\subsection{Rheological Properties}

Pilehvar et al. investigated the rheological parameters of complex modulus and phase angle. The microcapsules with a hydrophilic shell increase the elasticity and stiffness of the geopolymer-modified binder [76]. Geopolymer increased the failure temperature, viscosity, elastic modulus, and complex modulus and enhanced the binder's rutting resistance (Figure 11). The incorporation of higher percentages of geopolymer resulted in improved performance where binders modified with up to $8 \%$ high-purity quartz silica fume performed better than the unmodified asphalt binder [77]. The modifier constituents influence the viscoelastic properties of the asphalt binder [5].

According to Golestani et al. [76], modifiers can enhance the storage stability and the rheological properties of binders [78]. The addition of $5 \%$ of geopolymer FA with asphalt binder is able to resist stresses, strain, and better performance at high temperatures $[3,44,45]$. In addition, it is also able to enhance rutting resistance compared to conventional asphalt [79]. 


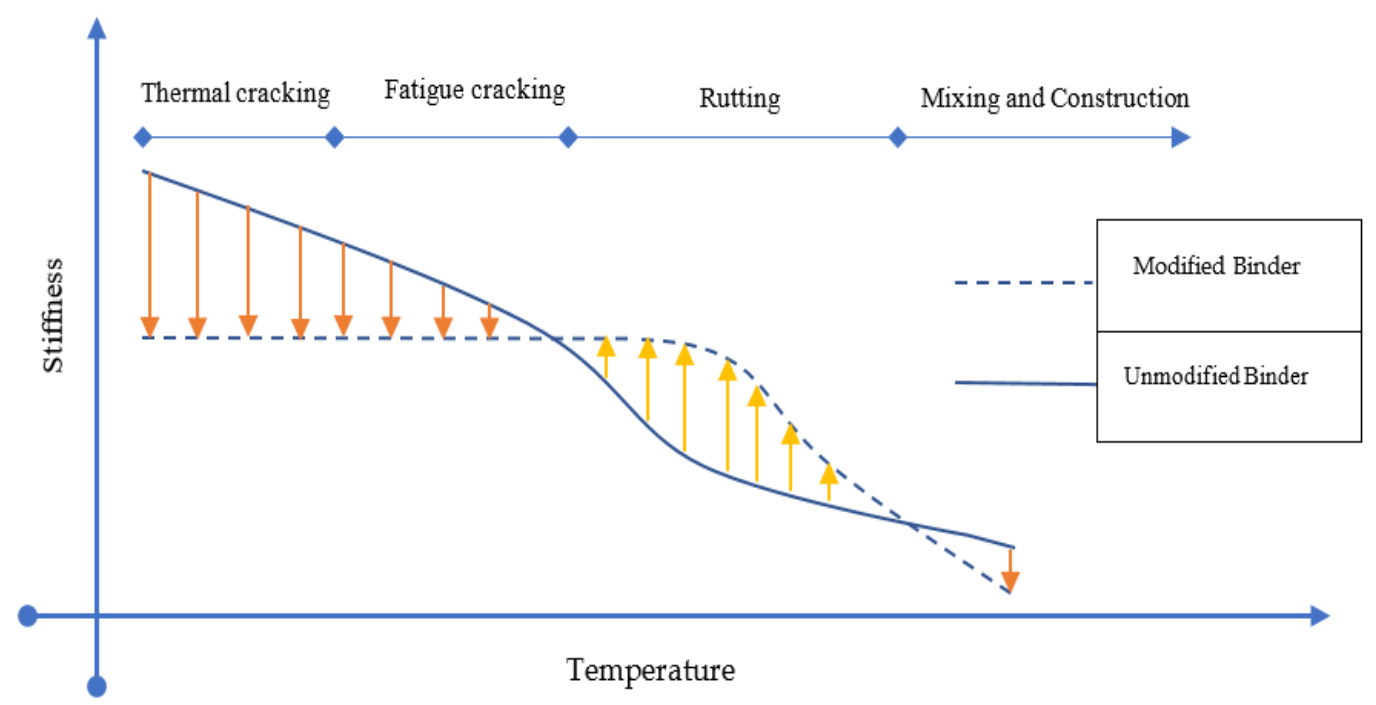

Figure 11. Improvements of geopolymer modifiers [79].

The phase angle $(\delta)$ ranges from $52{ }^{\circ} \mathrm{C}$ to $77^{\circ} \mathrm{C}$ in lag between the applied shear stress and the causing shear strain [38].

Rosyidi et al. observed that the incorporation of $9 \%$ geopolymer resulted in a marked increase of $8.58 \%$ in temperature susceptibility, higher shear modulus, and lower phase angle [2]. The addition of the same amount of geopolymer by mass of binder at $10 \mathrm{rad} / \mathrm{sec}$ and $58{ }^{\circ} \mathrm{C}$ resulted in an $86.6 \%$ increase in the rutting relative to the unmodified binder. Several comparative studies found that the geopolymer behaviour proceeds better enhancement than conventional modifiers and materials, and that the geopolymer reaction products are less affected by shear forces [42,80-82]. However, many of the previous studies focused on the impact of geopolymer-modified asphalt under high temperatures by testing the rheological and rutting properties $[5,55,76]$. Results show that using geopolymer results in improving modified binder resistance to permanent deformation at high temperatures. Studies by $[75,77]$ had investigated the impact of geopolymer on modified binder under low temperature. A study by [75] had investigated the ductility at the low temperature of $5{ }^{\circ} \mathrm{C}$, and results showed significant improvement of the rheological properties in terms of improving the complex shear modulus and phase angle. A similar trend has been found by [77] as using Bending Beam Rheometer BBR test at $-12{ }^{\circ} \mathrm{C}$ showed that the modified binder was less susceptible to low temperature cracking. Generally, geopolymer modification of asphalt binders resulted in significantly enhanced asphalt binder properties $[2,13,14,73,76,83,84]$. However, asphalt binder modification with $<0.2 \%$ geopolymer has an insignificant impact on binder properties. This study recommends adding a relatively high percentage $(>1.0 \%)$ of geopolymer for modifying the asphalt binder.

\section{Performance Characteristics of GMAM}

It is well known that the conventional asphalt materials do not meet the performance requirements for road construction that are constantly subjected to heavy loads, frequent stresses, heavy traffic, and various climatic and environmental conditions. Therefore, the asphalt materials must be modified using a suitable alternative to achieve the required properties that allow the pavement to withstand the stresses and distresses [79]. The modifier used in a specific project is determined by various factors, such as construction ability, availability, cost, and expected performance $[23,85,86]$. Relative to the existing additives for asphalt mixtures, geopolymers can reduce permanent deformations by more than $40 \%$ and are energy-efficient and eco-friendly. The significant microstructure enhancement during the mixing produced a new material with a different microstructure [81].

The addition of modifiers to asphalt binder mixtures increases binder stiffness at high service temperatures and thus resists rutting. Modifiers can produce softer binder 
mixtures at low service temperatures, minimising thermal cracking and improving the asphalt pavement's fatigue resistance [87]. Previous studies have shown that asphalt binders do not have excellent properties in heavy loads and high or low-temperature conditions $[42,81,82,88]$. It is softer in the high-temperature regions and more brittle in the cold temperature regions. Stiffer asphalt binder mixtures are more resistant to permanent deformation. Geopolymer modification of asphalt mixtures increases the mixture's elasticity and stiffness in hot climates [72,73] and enhances its elastic and engineering properties [3,89].

The current research on using geopolymer as a pavement material seeks to determine the feasibility of using waste materials as sustainable economic and environmental solutions [83]. Several studies have successfully used geopolymers to modify the material in asphalt applications. Most geopolymer-modified mixes meet the minimum strength criteria for high-volume roads [83].

Many researchers have investigated geopolymer properties in road applications to determine the standard design mixtures for GMA and reduce the need for high-temperature curing. Future research should investigate the long-term durability of GMA. Future research should also identify the environmental and economic benefits of using waste materials to produce GMA $[2,13,14,76]$. Geopolymers can enhance mechanical properties, damage resistance during operation, and reduce greenhouse emissions and energy consumption. Geopolymers can absorb toxic chemicals and reduce deformation in asphalt mixtures by up to $81 \%$ [25].

Higher geopolymer percentages and longer curing time can improve failure temperature, viscosity, and complex shear modulus. These have the effect of enhancing the rheological properties of asphalt binders. A higher geopolymer percentage also improved rutting resistance [18]. The increase in the failure temperature of asphalt binder modified with $9 \%$ geopolymer is $8.58 \%, 14.2 \%$, and $15.2 \%$ for curing periods of 2,7 , and 14 days. The incorporation of geopolymers of less than $5 \%$ has an insignificant impact on the mixing and compaction temperatures. However, a significant increase was observed in the compaction and mixing processes when asphalt mixtures are modified with $5 \%$ of FA geopolymer $[14,16,40]$.

The particles are well-dispersed in the binder. The incorporation of higher percentages of geopolymer did not change the binder's microstructure. Furthermore, the GPMA shows remarkable fatigue-cracking resistance in HMA, WMA, and RAP $[19,22,23,38]$.

Geopolymer-modified asphalt mixtures have low viscosity and resilient modulus. Modified asphalt mixtures have lower stiffness and density than the unmodified asphalt mixture $[19,20,42]$. Geopolymers satisfy the specifications set by the national road authority and are a suitable additive material for road constructions.

\section{Environmental and Social Benefit}

The environmental benefits of incorporating geopolymers in asphalt binders and asphalt mixtures include reduced emissions and fuel consumption because of the reduced extraction and transportation of virgin materials, reduced demand for non-renewable resources, and reduced landfill space used for the disposal of the used pavements. It also has a beneficial economic impact in developing countries where governments have to allocate a substantial budget to improve road infrastructure. [85]. The production of asphalt mixtures consumes a large amount of energy and releases $\mathrm{CO}_{2}$ into the atmosphere. Other raw materials contain minerals, and their usage for industrial production may be regulated by environmental threshold values [86]. Among the environmental benefits of using geopolymers are reduced demand for non-renewable resources and less extraction of virgin materials $[90,91]$. Other methods for improving the sustainability of asphalt mixture materials include using recycled geopolymers and improving asphalt mixtures durability.

The proposed treatment and synthesis of geopolymers such as zeolite involved environmentally friendly processes that do not require elevated pressure and temperature. Geopolymer sorbents can be synthesised utilising waste products, such as slags and FA [15]. 
In recent years, there is an increasing global effort to improve asphalt characteristics by using geopolymers and waste materials [85]. One study has shown that incorporating $15 \%$ geopolymer into asphalt mixtures reduces fossil fuel consumption, total cumulative energy requirement, and climate change by 13 to $14 \%$ [92].

\section{Economic Benefit}

Geopolymer additives are produced at ambient temperature using industrial byproducts to offer economic savings relative to conventional asphalt binder-based systems. The result of an analysis of life cycle costs by Dunmininu et al. showed that asphalt pavement binder is the most expensive component of asphalt pavement construction [93]. The life cycle cost analysis (LCCA) evaluates the economic implications of selected geopolymer materials on pavement construction in its design life [94]. Hoy et al. (2016) investigated Toxicity Characteristic Leaching Procedure (TCLP) and found that there is no environmental risk for RAP-FA geopolymer as pavement base layer [78]. Li et al. (2019) and several other researchers used FA as an alternative material to modify the conventional aggregates, a dynamic approach to reduce pavement cracking by developing the slow and expansive road-based stabilisers to recompense the shrinkage of road base materials [95]. The United Kingdom (UK) has limited the use of coal fuels for electricity generation. Only 1.6 million metric tons of FA were generated in the UK in 2016, a 70\% decrease from the amount produced in 2012. As of 2017, only $2 \%$ of the overall electricity consumption is from coal. Despite these efforts, $30-50 \%$ of FA are sent to landfills. The United Kingdom expects to cease using coal by 2025. Bakare et al. (2019) reported that, since 2017, India has been producing approximately 196 million tons of FA annually with a utilisation rate of almost 70\% [96]. However, only 55\% of the estimated $5.5 \mathrm{Mt} / \mathrm{a}$ FA produced in the power plants are used in various applications as general filler, grout, concrete additive, blocks, hydraulic binder, and the remaining $45 \%$ is transported to landfills [97]. The use of $20 \%$ FA geopolymer with RAP is economically viable for pavement-based applications.

\section{Conclusions}

This paper presents a comprehensive review of asphalt pavement construction based on the feasibility of using geopolymer asphalt modifiers for environmental, economic, and laboratory studies for the road construction industry.

The literature review revealed that more research has to be carried out to optimise the formulations for GPMA with enhanced properties. There have to be specific standards to increase the use of geopolymer in asphalt pavements. The following conclusions are drawn.

1. Geopolymers are a critical determiner of asphalt binder properties. Modification of asphalt binders with a high geopolymer percentage resulted in higher asphaltene content. It also resulted in enhanced rheological properties and physical properties of the modified asphalt binders. The incorporation of an optimal geopolymer percentage can reduce asphalt binder viscosity. Geopolymers can improve the workability of asphalt mixtures and reduce their mixing temperature.

2. Geopolymers can improve asphalt mixture's stability, fatigue resistance, rutting resistance, low temperature cracking, and reduce flowability.

3. The road construction industry has to increase the use of more environmentally friendly materials to ensure sustainability. Geopolymers are synthesised from waste products such as red mud, FA, mine waste, and blast furnace slag. The geopolymers in asphalt pavement materials provide a sustainable way of managing waste products. Geopolymers derived from slag, MK, and silica fume can reduce gas emissions and are suitable for hot and warm asphalt mixtures.

4. The currently available technologies and practices limit geopolymer utilisation in road construction because of the heat curing requirements for achieving adequate asphalt mixture properties. 
Author Contributions: Conceptualization, A.M.; formal analysis, A.M.; investigation, A.M. and A.M.B.; resources, A.M. and A.S.B.A.; writing—original draft preparation, A.M., A.S.B.A. and A.M.B.; writing-review and editing, Z.A.M., N.S.M., S.A. and N.I.M.Y.; supervision, N.I.M.Y.; funding acquisition, Z.A.M. All authors have read and agreed to the published version of the manuscript.

Funding: Prince Sultan University support for paying the Article Processing Charges (APC) of this publication.

Institutional Review Board Statement: Not applicable.

Informed Consent Statement: Informed consent was obtained from all subjects involved in the study.

Data Availability Statement: All data used in this research can be provided upon request.

Acknowledgments: The authors would like to thank Prince Sultan University for their financial support.

Conflicts of Interest: The authors declare no conflict of interest.

\section{References}

1. Luukkonen, T.; Abdollahnejad, Z.; Yliniemi, J.; Kinnunen, P.; Illikainen, M. One-part alkali-activated materials: A review. Cem. Concr. Res. 2018, 103, 21-34. [CrossRef]

2. Rosyidi, S.A.P.; Rahmad, S.; Yusoff, N.I.M.; Shahrir, A.H.; Ibrahim, A.N.H.; Ismail, N.F.N.; Badri, K.H. Investigation of the chemical, strength, adhesion and morphological properties of fly ash based geopolymer-modified bitumen. Construct. Build. Mater. 2020, 255, 119364. [CrossRef]

3. Milad, A.A.; Ali, A.S.B.; Yusoff, N.I.M. A review of the utilisation of recycled waste material as an alternative modifier in asphalt mixtures. Civ. Eng. J. 2020, 6, 42-60. [CrossRef]

4. Omar, H.A.; Yusoff, N.I.M.; Mubaraki, M.; Ceylan, H. Effects of moisture damage on asphalt mixtures. J. Traffic Trans. Eng. 2020, 7, 600-628.

5. Tang, N.; Alrefaei, Y.; Dai, J.G. The implementation of geopolymer as an additive of warm-mix asphalt to reduce emissions. In Proceedings of the CPS 2019-International Conference on Cleaner Production \& Sustainability, Hong Kong, China, 30 October-2 November 2019.

6. Li, L.; Wu, S.; Liu, G.; Cao, T.; Amirkhanian, S. Effect of organo-montmorillonite nanoclay on VOCs inhibition of bitumen. Construct. Build. Mater. 2017, 146, 429-435. [CrossRef]

7. Tang, N.; Deng, Z.; Dai, J.-G.; Yang, K.; Chen, C.; Wang, Q. Geopolymer as an additive of warm mix asphalt: Preparation and properties. J. Clean. Prod. 2018, 192, 906-915. [CrossRef]

8. Ibrahim, A.N.H.; Yusoff, N.I.M.; Akhir, N.M.; Borhan, M.N. Physical properties and storage stability of geopolymer modified asphalt binder. J. Teknol. 2016, 78, 133-138. [CrossRef]

9. Cheraghian, G.; Falchetto, A.C.; You, Z.; Chen, S.; Kim, Y.S.; Westerhoff, J.; Moon, K.H.; Wistuba, M.P. Warm mix asphalt technology: An up to date review. J. Clean. Prod. 2020, 268, 122128. [CrossRef]

10. Behnood, A.; Gharehveran, M.M. Morphology, rheology, and physical properties of polymer-modified asphalt binders. Eur. Polym. J. 2019, 112, 766-791. [CrossRef]

11. Chen, Q.; Wang, C.; Qiao, Z.; Guo, T. Graphene/tourmaline composites as a filler of hot mix asphalt mixture: Preparation and properties. Construct. Build. Mater. 2020, 239, 117859. [CrossRef]

12. Hoy, M.; Rachan, R.; Horpibulsuk, S.; Arulrajah, A.; Mirzababaei, M. Effect of wetting-drying cycles on compressive strength and microstructure of recycled asphalt pavement-Fly ash geopolymer. Construct. Build. Mater. 2017, 144, 624-634. [CrossRef]

13. Dayal, S.; Soundarapandian, N. Effect of fly-ash based geopolymer coated aggregate on bituminous mixtures. Građevinar 2018, 70, 187-199.

14. Huynh, A.T.; Magee, B.; Woodward, D. A preliminary characterisation of innovative semi-flexible composite pavement comprising geopolymer grout and reclaimed asphalt planings. Materials 2020, 13, 3644. [CrossRef]

15. Hoy, M.; Horpibulsuk, S.; Arulrajah, A.; Mohajerani, A. Strength and microstructural study of recycled asphalt pavement: Slag geopolymer as a pavement base material. J. Mater. Civ. Eng. 2018, 30, 4018177. [CrossRef]

16. Odion, D.; Khattak, M.J.; Abader, M.; Heim, N. Soil-geopolymer mixtures using recycled concrete aggregates for base and subbase layers. In Proceedings of the MATEC Web of Conferences, Sibiu, Romania, 5-7 June 2019; EDP Sciences: Les Ulis, France, 2019; Volume 271, p. 2003.

17. Kuenzel, C.; Neville, T.P.; Donatello, S.; Vandeperre, L.; Boccaccini, A.R.; Cheeseman, C.R. Influence of metakaolin characteristics on the mechanical properties of geopolymers. Appl. Clay Sci. 2013, 83, 308-314. [CrossRef]

18. Hamid, A.; Alfaidi, H.; Baaj, H.; El-Hakim, M. Evaluating fly ash-based geopolymers as a modifier for asphalt binders. Adv. Mater. Sci. Eng. 2020, 2020, 1-11. [CrossRef]

19. Hoy, M.; Horpibulsuk, S.; Arulrajah, A. Strength development of Recycled Asphalt Pavement-Fly ash geopolymer as a road construction material. Construct. Build. Mater. 2016, 117, 209-219. [CrossRef]

20. Khan, M.I.; Huat, H.Y.; Dun, M.H.; Bin, M.; Sutanto, M.H.; Jarghouyeh, E.N.; Zoorob, S.E. Effect of irradiated and non-irradiated waste PET based cementitious grouts on flexural strength of semi-flexible pavement. Materials 2019, 12, 4133. [CrossRef] 
21. Bai, T.; Song, Z.; Wang, H.; Wu, Y.; Huang, W. Performance evaluation of metakaolin geopolymer modified by different solid wastes. J. Clean. Prod. 2019, 226, 114-121. [CrossRef]

22. Ariyadasa, P.W.; Nataatmadja, A. The use of geopolymer as supplementary binder in foamed bitumen stabilisation. In Proceedings of the 18th AAPA International Flexible Pavements Conference, Sydney, NSW, Australia, 18-21 August 2019.

23. Khater, H.M. Effect of silica fume on the characterisation of the geopolymer materials. Int. J. Adv. Struct. Eng. 2013, 5, 12. [CrossRef]

24. Woszuk, A.; Bandura, L.; Franus, W. Fly ash as low cost and environmentally friendly filler and its effect on the properties of mix asphalt. J. Clean. Prod. 2019, 235, 493-502. [CrossRef]

25. Ismail, M.A. Creep Properties of Geopolymer Bituminous Mixtures. Bachelor's Thesis, Universiti Teknologi Petronas, Seri Iskandar, Malaysia, 2011.

26. Terzano, R.; Spagnuolo, M.; Medici, L.; Tateo, F.; Ruggiero, P. Characterization of different coal fly ashes for their application in the synthesis of zeolite $X$ as cation exchanger for soil remediation. Fresen. Environ. Bull. 2005, 14, $263-267$.

27. Fauzi, A.; Nuruddin, M.F.; Malkawi, A.B.; Abdullah, M.M.A.B. Study of fly ash characterization as a cementitious material. Procedia Eng. 2016, 148, 487-493. [CrossRef]

28. Nmiri, A.; Hamdi, N.; Yazoghli-Marzouk, O.; Duc, M.; Srasra, E. Synthesis and characterisation of kaolinite-based geopolymer: Alkaline activation effect on calcined kaolinitic clay at different temperatures. J. Mater. Environ. Sci. 2017, 8, 676-690.

29. Khan, M.I.; Khan, H.U.; Azizli, K.; Sufian, S.; Man, Z.; Siyal, A.A.; Muhammad, N.; ur Rehman, M.F. The pyrolysis kinetics of the conversion of Malaysian kaolin to Metakaolin. Appl. Clay Sci. 2017, 146, 152-161. [CrossRef]

30. Oderji, S.Y.; Chen, B.; Ahmad, M.R.; Shah, S.F.A. Fresh and hardened properties of one-part fly ash-based geopolymer binders cured at room temperature: Effect of slag and alkali activators. J. Clean. Prod. 2019, 225, 1-10. [CrossRef]

31. Rovnaník, P. Effect of curing temperature on the development of hard structure of metakaolin-based geopolymer. Construct. Build. Mater. 2010, 24, 1176-1183. [CrossRef]

32. Alehyen, S.; Achouri, M.E.L.; Taibi, M. Characterization, microstructure and properties of fly ash-based geopolymer. J. Mater. Environ. Sci. 2017, 8, 1783-1796.

33. Heah, C.Y.; Kamarudin, H.; Al Bakri, A.M.M.; Binhussain, M.; Luqman, M.; Nizar, I.K.; Ruzaidi, C.M.; Liew, Y.M. Effect of curing profile on kaolin-based geopolymers. Phys. Procedia 2011, 22, 305-311. [CrossRef]

34. Li, Y.; Wang, W.; Zhou, C.; Huang, F. First-principles calculations of equilibrium silicon isotope fractionation in metamorphic silicate minerals. Solid Earth Sci. 2019, 4, 142-149. [CrossRef]

35. Sutharsan, T. Quantification of Cohesive Healing of Asphalt Binder Based on Dissipated Energy Analysis. Master's Thesis, Washington State University, Washington, DC, USA, 2010.

36. Chindaprasirt, P.; Chareerat, T.; Sirivivatnanon, V. Workability and strength of coarse high calcium fly ash geopolymer. Cem. Concr. Compos. 2007, 29, 224-229. [CrossRef]

37. Mohammed, S. Processing, effect and reactivity assessment of artificial pozzolans obtained from clays and clay wastes: A review. Construct. Build. Mater. 2017, 140, 10-19. [CrossRef]

38. Ridzuan, A.R.M.; Khairulniza, A.A.; Fadzil, M.A.; Nurliza, J.; Fauzi, M.A.M.; Yusoff, W. Alkaline activators concentration effect to strength of waste paper sludge ash-based geopolymer mortar. In InCIEC 2013; Springer: Singapore, 2014; pp. 169-175.

39. Tang, N.; Yang, K.; Alrefaei, Y.; Dai, J.-G.; Wu, L.-M.; Wang, Q. Reduce VOCs and PM emissions of warm-mix asphalt using geopolymer additives. Construct. Build. Mater. 2020, 244, 118338. [CrossRef]

40. Camargo, I.G.D.; Hofko, B.; Mirwald, J.; Grothe, H. Effect of Thermal and Oxidative Aging on Asphalt Binders Rheology and Chemical Composition. Materials 2020, 13, 4438. [CrossRef] [PubMed]

41. Ali, S.I.A.; Yahia, H.A.M.; Ibrahim, A.N.H.; Al Mansob, R.A. High temperatures performance investigation of geopolymer modified bitumen binders. In Proceedings of the Tenth International Conference on the Bearing Capacity of Roads, Railways and Airfields, Athens, Greece, 28-30 June 2017.

42. Ali, S.I.A.; Ismail, A.; Karim, M.R.; Yusoff, N.I.M.; Al-Mansob, R.A.; Aburkaba, E. Performance evaluation of Al2O3 nanoparticlemodified asphalt binder. Road Mater. Pavem. Design 2017, 18, 1-18. [CrossRef]

43. Ibrahim, A.N.H.; Ahmad, A.S.; Mohd Akhir, N.; Borhan, M.N. Performance evaluation of stone mastic asphalt (SMA) using geopolymer as an asphalt modifier. Jordan J. Civ. Eng. 2016, 10, 442-450.

44. Huang, X.; Eldouma, I.B. Experimental study to determine the most preferred additive for improving asphalt performance using polypropylene, crumb rubber, and tafpack super in medium and high-temperature range. Appl. Sci. 2019, 9, 1567.

45. Abdel-Wahed, T.; Rashwan, N.K.; Maurice, A.E. The physical properties of bitumen modified with ilmenite and bentonite nanoparticles. HBRC J. 2019, 16, 335-350. [CrossRef]

46. Zafari, F.; Rahi, M.; Moshtagh, N.; Nazockdast, H. The improvement of bitumen properties by adding NanoSilica. Stud. Civ. Eng. Arch. 2014, 3, 62-69.

47. Bowers, B.F.; Huang, B.; Shu, X.; Miller, B.C. Investigation of reclaimed asphalt pavement blending efficiency through GPC and FTIR. Construct. Build. Mater. 2014, 50, 517-523. [CrossRef]

48. Yao, H.; Dai, Q.; You, Z. Fourier transform infrared spectroscopy characterisation of aging-related properties of original and nano-modified asphalt binders. Construct. Build. Mater. 2015, 101, 1078-1087. [CrossRef]

49. Ezzat, H.; El-Badawy, S.; Gabr, A.; Zaki, E.-S.I.; Breakah, T. Evaluation of asphalt binders modified with nanoclay and nanosilica. Procedia Eng. 2016, 143, 1260-1267. [CrossRef] 
50. Silva, H.; Machado, A.; Oliviera, J.; Costa, L. Waste polymers recycling in high performance asphalt mixtures. In Proceedings of the 1st International Conference WASTES: Solutions, Treatments and Opportunities, Guimarães, Portugal, 12-14 September 2011; pp. 1-6.

51. Burduhos Nergis, D.D.; Vizureanu, P.; Ardelean, I.; Sandu, A.V.; Corbu, O.C.; Matei, E. Revealing the influence of microparticles on geopolymers' synthesis and porosity. Materials 2020, 13, 3211. [CrossRef] [PubMed]

52. Sore, S.O.; Messan, A.; Prud'Homme, E.; Escadeillas, G.; Tsobnang, F. Stabilization of compressed earth blocks (CEBs) by geopolymer binder based on local materials from Burkina Faso. Construct. Build. Mater. 2018, 165, 333-345. [CrossRef]

53. Dehouche, N.; Kaci, M.; Mokhtar, K.A. Influence of thermo-oxidative aging on chemical composition and physical properties of polymer modified bitumens. Construct. Build. Mater. 2012, 26, 350-356. [CrossRef]

54. Nasvi, M.C.M.; Ranjith, P.G.; Sanjayan, J. Comparison of mechanical behaviors of geopolymer and class G cement as well cement at different curing temperatures for geological sequestration of carbon dioxide. In Proceedings of the 46th US rock mechanics/geomechanics symposium; American Rock Mechanics Association, Chicago, IL, USA, 24-27 June 2012.

55. Polacco, G.; Filippi, S.; Merusi, F.; Stastna, G. A review of the fundamentals of polymer-modified asphalts: Asphalt/polymer interactions and principles of compatibility. Adv. Coll. Interf. Sci. 2015, 224, 72-112. [CrossRef]

56. Hafeez, I.; Kamal, M.A.; Ahadi, M.R.; Shahzad, Q.; Bashir, N. Performance prediction of hot mix asphalt from asphalt binders. Pak. J. Eng. Appl. Sci. 2012, 11, 104-113.

57. Zhang, L.; Ahmari, S.; Zhang, J. Synthesis and characterisation of fly ash modified mine tailings-based geopolymers. Construct. Build. Mater. 2011, 25, 3773-3781. [CrossRef]

58. Soleimani, M.A.; Naghizadeh, R.; Mirhabibi, A.R.; Golestanifard, F. Effect of calcination temperature of the kaolin and molar $\mathrm{Na} 2 \mathrm{O} / \mathrm{SiO} 2$ activator ratio on physical and microstructural properties of Metakaolin based geopolymers. Iran. J. Mater. Sci. Eng. 2012, 9, 43-51.

59. Yusoff, N.I.M.; Breem, A.A.S.; Alattug, H.N.M.; Hamim, A.; Ahmad, J. The effects of moisture susceptibility and ageing conditions on nano-silica/polymer-modified asphalt mixtures. Construct. Build. Mater. 2014, 72, 139-147. [CrossRef]

60. Snellings, R.; Mertens, G.; Elsen, J. Supplementary cementitious materials. Rev. Mineral. Geochem. 2012, 74, 211-278. [CrossRef]

61. Si, R.; Dai, Q.; Guo, S.; Wang, J. Mechanical property, nanopore structure and drying shrinkage of metakaolin-based geopolymer with waste glass powder. J. Clean. Prod. 2020, 242, 118502. [CrossRef]

62. Steven, H.; Kerkhoff, B.; Kosmatka, W.C.P. Fly ash, slag, silica fume, and natural pozzolans. In Design and Control of Concrete Mixtures, 14th ed.; Portland Cement Association: Skokie, IL, USA, 2002; pp. 57-72.

63. Luukkonen, T.; Sarkkinen, M.; Kemppainen, K.; Rämö, J.; Lassi, U. Metakaolin geopolymer characterisation and application for ammonium removal from model solutions and landfill leachate. Appl. Clay Sci. 2016, 119, 266-276. [CrossRef]

64. Skorina, T. Ion exchange in amorphous alkali-activated aluminosilicates: Potassium based geopolymers. Appl. Clay Sci. 2014, 87, 205-211. [CrossRef]

65. O'Connor, S.J.; MacKenzie, K.J.D.; Smith, M.E.; Hanna, J.V. Ion exchange in the charge-balancing sites of aluminosilicate inorganic polymers. J. Mater. Chem. 2010, 20, 10234-10240. [CrossRef]

66. Khalid, H.R.; Lee, N.K.; Choudhry, I.; Wang, Z.; Lee, H.K. Evolution of zeolite crystals in geopolymer-supported zeolites: Effects of composition of starting materials. Mater. Lett. 2019, 239, 33-36. [CrossRef]

67. Aïcin, P.-C. Supplementary cementitious materials and blended cements. In Science and Technology of Concrete Admixtures; Elsevier: Amsterdam, The Netherlands, 2016; pp. 53-73.

68. Abutalib, N.; Karnati, S.R.; Oldham, D.; Zhang, L.; Fini, E. Surface Modification of silica fume with amine groups to reduce agglomeration and improve asphalt resistance to oxidation. Res. Rev. J. Mater. Sci. 2017, 4. [CrossRef]

69. Zhang, J.; Li, H.; Liu, P.; Liang, M.; Jiang, H.; Yao, Z.; Airey, G. Experimental exploration of influence of recycled polymer components on rutting resistance and fatigue behavior of asphalt mixtures. J. Mater. Civ. Eng. 2020, 32, 4020129. [CrossRef]

70. Chirila, E.; Draghici, C. Risk assessment of mixtures of chemical pollutants in the environment. In Exposure and Risk Assessment of Chemical Pollution - Contemporary Methodology; Springer: Berlin/Heidelberg, Germany, 2009; pp. 51-67.

71. Xiao, F.; Amirkhanian, S.; Juang, C.H. Rutting resistance of rubberised asphalt concrete pavements containing reclaimed asphalt pavement mixtures. J. Mater. Civ. Eng. 2007, 19, 475-483. [CrossRef]

72. Duxson, P.; Provis, J.L.; Lukey, G.C.; Mallicoat, S.W.; Kriven, W.M.; Van Deventer, J.S. Understanding the relationship between geopolymer composition, microstructure and mechanical properties. Coll. Surf. A 2005, 269, 47-58. [CrossRef]

73. Peng, Y.; Xia, S.; Xu, Y.R.; Lu, X.Y.; Li, Y.W. Application of recycled polyethylene terephthalate fiber in asphaltic mix for fatigue life improvement. Discrete-element modeling of influence of void characteristics on uniaxial penetration strength of asphalt mixtures. J. Mater. Civ. Eng. 2021, 33, 04020399. [CrossRef]

74. Amirkhanian, A.N.; Xiao, F. Characterisation of unaged asphalt binder modified with carbon nano particles. Int. J. Pavem. Res. Technol. 2011, 4, 1997.

75. Pilehvar, S.; Szczotok, A.M.; Carmona, M.; Pamies, R.; Kjøniksen, A. The effect of micro-encapsulated phase change materials on the rheology of geopolymer and Portland cement mortar. J. Am. Ceram. Soc. 2020, 103, 5852-5869. [CrossRef]

76. Golestani, B.; Hyun, B.; Moghadas, F.; Fallah, S. Nanoclay application to asphalt concrete: Characterisation of polymer and linear nanocomposite-modified asphalt binder and mixture. Construct. Build. Mater. 2015, 91, 32-38. [CrossRef] 
77. Al Allam, A.M.; Masirin, M.I.M.; Abdullah, M.E.; Bader, A.S. Evaluation of the permanent deformations and aging conditions of Batu Pahat soft clay-modified asphalt mixture by using a dynamic creep test. In Proceedings of the MATEC Web of Conferences, Melaka, Malaysia, 1-2 December 2015; Volume 47, pp. 1-7.

78. Hoy, M.; Horpibulsuk, S.; Rachan, R.; Chinkulkijniwat, A.; Arulrajah, A. Recycled asphalt pavement-fly ash geopolymers as a sustainable pavement base material: Strength and toxic leaching investigations. Sci. Total Environ. 2016, 573, 19-26. [CrossRef]

79. Ragab, A.; Farag, R.K.; Kandil, U.F.; El-Shafie, M.; Saleh, A.; El-Kafrawy, A.F. Thermo-mechanical properties improvement of asphalt binder by using methylmethacrylate/ethylene glycol dimethacrylate. Egypt. J. Pet. 2016, 25, 397-407. [CrossRef]

80. Idrus, M.; Masirin, M.; Ali, A.S.B.; Mustapa, M.S.; Rahman, R.A.; Wagiman, A.; Aziz, M.I.; Mohd Masirin, M.I.; Ali, A.S.B.; Mustapa, M.S.; et al. Analysis of physical and microstructural properties on parit nipah peat particles as sustainable asphalt modifier. Mater. Sci. Forum 2020, 975, 197-202. [CrossRef]

81. Albrka Ali, S.I.; Ismail, A.; Yusoff, N.I.M.; Hassan, N.A.; Ibrahim, A.N.H. Characterization of the performance of aluminum oxide nanoparticles modified asphalt binder. J. Teknol. 2016, 78, 91-96. [CrossRef]

82. Brasileiro, L.; Moreno-Navarro, F.; Tauste-Martínez, R.; Matos, J.; Rubio-Gámez, M.D.C. Reclaimed polymers as asphalt binder modifiers for more sustainable roads: A review. Sustainability 2019, 11, 646. [CrossRef]

83. Avirneni, D.; Peddinti, P.R.T.; Saride, S. Durability and long term performance of geopolymer stabilised reclaimed asphalt pavement base courses. Construct. Build. Mater. 2016, 121, 198-209. [CrossRef]

84. Zarina, Y.; Mohd Mustafa Al Bakri, A.; Kamarudin, H.; Nizar, K.; Rafiza, A.R. Review on the various ash from palm oil waste as geopolymer material. Rev. Adv. Mater. Sci. 2013, 34, 37-43.

85. Masi, G.; Manzi, S.; Bignozzi, M.C. Gender balance in construction material research: The analysis of alkali-activated materials by a bibliometric study using scopus database. Front. Mater. 2020, 7, 321.

86. Bagui, S.K.; Das, A.; Verma, K.K.; Bagui, S. Variation of pavement design with environmental temperature variation. Malays. J. Civ. Eng. 2017, 29. [CrossRef]

87. Milad, A.; Ahmeda, A.G.F.; Taib, A.M.; Rahmad, S.; Solla, M.; Yusoff, N.I.M. A review of the feasibility of using crumb rubber derived from end-of-life tire as asphalt binder modifier. J. Rubber Res. 2020, 23, 203-216. [CrossRef]

88. Milad, A.; Taib, A.M.; Ahmeda, A.G.F.; Solla, M.; Yusoff, N.I.M. A review of the use of reclaimed asphalt pavement for road paving applications. J. Teknol. 2020, 82, 3. [CrossRef]

89. Khattak, M.; Odion, D. Soil-Recycled Aggregate-Geopolymer Road Base/Subbase Mixtures: Steps Towards Sustainability; University of Louisiana at Lafayette: Lafayette, LA, USA, 2019.

90. Al-Qadi, I.L.; Ozer, H.; Harvey, J. Pavement Life-Cycle Assessment: Proceedings of the Symposium on Life-Cycle Assessment of Pavements, CRC Press: Champaign, IL, USA, 2017; ISBN 1351659219.

91. Weil, M.; Dombrowski, K.; Buchwald, A. Life-cycle analysis of geopolymers. In Geopolymers; Elsevier: Amsterdam, The Netherlands, 2009; pp. 194-210.

92. Vidal, R.; Moliner, E.; Martínez, G.; Rubio, M.C. Life cycle assessment of hot mix asphalt and zeolite-based warm mix asphalt with reclaimed asphalt pavement. Resour. Conservat. Recycl. 2013, 74, 101-114. [CrossRef]

93. Dunmininu, A. Waste materials in highway applications: An overview on generation and utilisation implications on sustainability. J. Clean. Prod. 2020, 283, 124581.

94. Li, J.; Xiao, F.; Zhang, L.; Amirkhanian, S.N. Life cycle assessment and life cycle cost analysis of recycled solid waste materials in highway pavement: A review. J. Clean. Prod. 2019, 233, 1182-1206. [CrossRef]

95. Li, J.; Shen, W.; Zhang, B.; Ji, X.; Chen, X.; Ma, W.; Hu, J.; Zhou, M.; Li, Y. Investigation on the preparation and performance of clinker-fly ash-gypsum road base course binder. Construct. Build. Mater. 2019, 212, 39-48. [CrossRef]

96. Bakare, M.D.; Pai, R.R.; Patel, S.; Shahu, J.T. Environmental sustainability by bulk utilisation of fly ash and GBFS as road subbase materials. J. Hazard. Toxic Radioact. Waste 2019, 23, 4019011. [CrossRef]

97. Hassan, K.E.; Elghali, L.; Sowerby, C.R. Development of New Materials for Secondary and Recycled Aggregates in Highway Infrastructure; TRL: Crowthorne, UK, 2004. 